\title{
Causal Nexus between Economic Growth, Banking Sector Development, Stock Market Development, and Other Macroeconomic Variables: The Case of ASEAN Countries
}

${ }^{a}$ Rudra P. Pradhan, Vinod Gupta School of Management, Indian Institute of Technology Kharagpur,WB 721302, India.Email: rudrap@vgsom.iitkgp.ernet.in [Corresponding Author]

${ }^{b}$ Mak B. Arvin, Department of Economics, Trent University, Peterborough, Ontario K9J 7B8, Canada.Email: marvin@trentu.ca

c John H. Hall, Department of Financial Management, University of Pretoria, Pretoria 0028, Republic of South Africa. E-mail: john.hall@up.ac.za

${ }^{d}$ Sahar Bahmani, Department of Economics, University of Wisconsin at Parkside, Kenosha, Wisconsin 53144, USA. Email: bahmani@uwp.edu 


\section{Graphical Abstract: For Review}

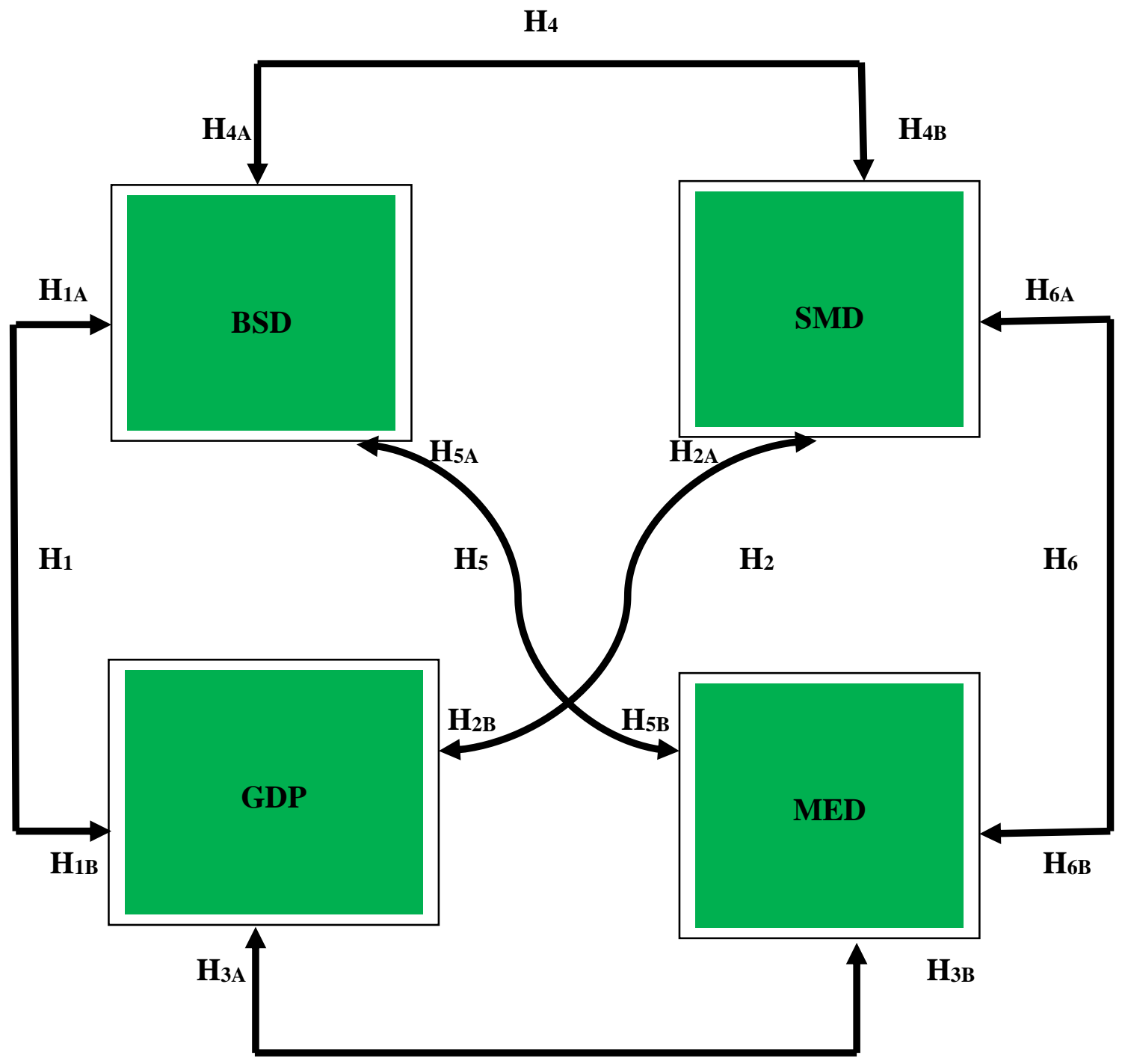

$\mathbf{H}_{3}$

Note 1: GDP is per capita economic growth rate; BSD is banking sector development; SMD is stock market development, and MED is macroeconomic development comprised of four macroeconomic variables: FDI, OPE, INF, and GCE.

Note 2: FDI: Foreign direct investment; OPE: Trade openness; INF: inflation rate; and GCE: Government consumption expenditure.

Note 3:

$\mathrm{H}_{1 \mathrm{~A}, \mathrm{~B}}$ : Banking sector development Granger-causes economic growth and vice versa.

$\mathrm{H}_{2 \mathrm{~A}, \mathrm{~B}}$ : Stock market development Granger-causes economic growth and vice versa.

$\mathrm{H}_{3 \mathrm{~A}, \mathrm{~B}}$ : A macroeconomic determinant Granger-causes economic growth and vice versa.

$\mathrm{H}_{4 \mathrm{~A}}$, $\mathrm{B}$ : Banking sector development Granger-causes stock market development and vice versa.

$\mathrm{H}_{5 \mathrm{~A}, \mathrm{~B}}$ : Banking sector development Granger-causes a macroeconomic determinant and vice versa.

$\mathrm{H}_{6 \mathrm{~A}, \text { в }}$ : Stock market development Granger-causes a macroeconomic determinant and vice versa. 


\section{Highlights: For Review}

- This study uses banking sector development, stock market development, and macroeconomic variables to investigate the cointegration and Granger causality.

- The study combines the different strands of the literature.

- We study ASEAN countries over 1961-2012 and employ a panel vector auto-regressive model for detecting the direction of causality between the variables.

- Our novel panel data estimation methods allow us to identify the important causal links among the variables, both in the short run and in the long run. 


\begin{abstract}
This paper examines the relationship between banking sector development, stock market development, economic growth, and four other macroeconomic variables in ASEAN countries for the period 1961-2012. Using principal component analysis for the construction of the development indices and a panel vector auto-regressive model for testing the Granger causalities, this study finds the presence of both unidirectional and bidirectional causality links between these variables. The study contributes to understanding the importance of the interrelationship between the variables and combines the different strands of the literature. It also contributes to the literature by focusing on a group of countries that have not been studied before. One particular policy recommendation is to make the banking sector more accessible for those country's inhabitants that do not have bank accounts. Another policy recommendation is to nurture stock market development, which will facilitate the increased raising of capital for investment purposes to enhance economic growth.
\end{abstract}

Keywords: Banking sector, Stock market, Economic growth, Granger causality, ASEAN countries

JEL Classification: O43, O16, E44, E31 


\section{Introduction}

The level of banking sector development and stock market development are among the most important variables identified by the empirical economic growth literature as being correlated with growth performance across countries (Fink et al., 2009; Yartey, 2008; Naceur et al., 2007; Beck and Levine, 2004; Garcia and Liu, 1999; Levine and Zervos, 1998). These development challenges prevent developing countries from taking full advantage of technology transfer, causing some of these countries to diverge from the growth rate of the world production frontier (Menyah et al., 2014; Aghion et al., 2005). In fact, it is debated that poor countries with a weakened financial system are trapped in a vicious circle, where low levels of financial development, in both the banking sector and the stock market, lead to low economic performance and low economic performance leads to low financial development (Fung, 2009). An inadequately supervised financial system may be crisis-prone, with potentially devastating effects (Moshirian and Wu, 2012; OECD, 1999). On the contrary, an efficient financial system, with a well-developed and integrated banking sector and stock market, provides better financial services, which enables an economy to increase its growth rate (Esso, 2010; Bencivenga et al., 1995; King and Levine, 1993a). Hence, finance is not only pro-growth but it is also pro-poor, suggesting that financial development helps the poor catch up with the rest of the economy as it grows (Demirguc-Kunt and Levine, 2009). Furthermore, the endogenous growth theory as articulated by Greenwood and Jovanovic (1990) and Bencivenga and Smith (1991) and others stresses that financial development, both banking sector development and stock market development, is a key factor that fosters long-run economic growth, as financial development along with advancement is able to facilitate economic growth through multiple channels. These channels include: (i) providing information about possible investments, so as to allocate capital 
efficiently; (ii) monitoring firms and exerting corporate governance; (iii) risk diversification; (iv) mobilizing and pooling savings; (v) easing the exchange of goods and services; and (vi) technology transfer (see, for example, Zhang et al, 2012; Levine, 2005; Garcia and Liu, 1999; Fritz, 1984; Drake, 1980).

Not surprisingly, the relationship between financial development ${ }^{1}$ and economic growth has been an important area of discussion among researchers and policy makers (see, for instance, Herwartz and Walle, 2014; Bangake and Eggoh, 2011; Chow and Fung, 2011; Mukhopadhyay et al., 2011; Yucel, 2009; Ang, 2008; Wachtel, 2003; Levine, 2003; Fase and Abma, 2003; AlYousif, 2002; Levine et al., 2000; Beck et al., 2000; King and Levine, 1993a, 1993b; Jung, 1986). However, what remains unclear is the issue of cointegration and causality between banking sector development and stock market development. Development economics studies two types of relationships: first, the link between banking sector development and economic growth (Menyah et al., 2014; Moshirian and Wu, 2012; Majid and Mahrizal, 2007; Tang, 2005; Christopoulos and Tsionas, 2004); and second, the link between stock market development and economic growth (Khan, 2004; Choong et al., 2003; Singh, 1997; Levine, 1991). In a broadspectrum, both banking sector development and stock market development are main forces that can bring about high economic growth in a country (Fink et al., 2006; Castaneda, 2006; Nieuwerburgh et al., 2006; Trew, 2006; Shan et al., 2001; Bilson et al., 2001; Gjerde and Saettem, 1999; Kwon and Shin, 1999; Garcia and Liu, 1999; Pagano, 1993; Shaw, 1973; Schumpeter, 1911). It has been argued in a subset of the finance-growth literature that both

\footnotetext{
${ }^{1}$ Financial development is defined in terms of the aggregate size of the financial sector, its sectorial composition, and a range of attributes of individual sectors that determine their effectiveness in meeting users' requirements. The evaluation of financial structure should cover the roles of the key institutional players, including the central bank, commercial and merchant banks, saving institutions, development financial institutions, insurance companies, mortgage entities, pension funds, the stock market, and other financial market institutions (see, for instance, Zaman et al., 2012; IMF, 2005). Thus, financial development includes both banking sector development and stock market development.
} 
banking sector development and stock market development can cause each other (Cheng, 2012; Allen et al., 2012; Cheng, 2012; Gimet and Lagoarde-Segot, 2011). While policymakers may vary on the degree to which these financial-sector developments contribute to economic growth, they generally concur that both do in fact matter. As a result, many countries have adopted development strategies that prioritize banking sector development and stock market development. ASEAN regional forum (ARF) countries are no exception. Since the end of the 1980s, these countries have bolstered their banking sector and stock market evolution by reducing governmental intervention in the financial sector, generally, and in the banking sectors and/or stock markets, in particular. Such policies are expected to promote economic growth, among other things, through the enhanced mobilization of savings and increases in domestic and foreign investment (King and Levine, 1993a; Levine and Zervos, 1996; Masih and Masih, 1999; Reinhart and Tokatlidis, 2003; Thornton, 1994). However, to ascertain that such policies are undeniably guaranteed to be effective, it must be formally established that there is indeed a causal relationship between banking sector development, stock market development, and economic growth (Cheng, 2012; Zhang et al., 2012; Hassan et al., 2011; Colombage, 2009; Gries et al., 2009; Cole et al., 2008; Naceur and Ghazouani, 2007; Panopoulou, 2009; Rousseau, 2009; Choe and Moosa, 1999).

In this paper, we seek to answer questions concerning the nature of the causal relationship between economic growth, banking sector development, stock market development, and four other macroeconomic variables. The novel features of this study are that: (1) we use the group of 26 ARF countries over a long span of time, from 1961- 2012; (2) we combine the different strands of the literature; and (2) we employ principal component analysis and a panel vector 
auto-regressive (VAR) model for testing the Granger causalities. These formulations are rarely used in the finance-growth literature.

The remainder of this paper is structured as follows: Section 2 provides a literature review on the connection between banking sector development, stock market development, and economic growth. Section 3 highlights the research questions and the proposed hypotheses. Section 4 presents the data structure, sample selection, and the variables. This is followed by Section 5, which outlines our empirical model. Results are discussed in Section 6, while the final section concludes with a summary and the policy implications of our results.

\section{Literature Review}

Financial development is pivot to economic growth (Graff, 2003; Levine, 1997). The connection between the two variables has been the focus of an immense body of theoretical and empirical research since the seminal work Schumpeter (1973). A number of studies (Uddin et al., 2014; Herwartz and Walle, 2014; Hsueh et al., 2013; Pradhan, 2013; Fung (2009); Beck et al., 2005; Dritsakis and Adamopoulos, 2004; Beck and Levine, 2004; Fase and Abama, 2003; Craigwell et al., 2001; Blackburn and Hung, 1998; Rajan and Zingales, 1998; Greenwood and Bruce, 1997;Greenwood and Smith, 1997; Berthelemy and Varoudakis, 1996; Gregorio and Guidotti, 1995; Thornton, 1994; King and Levine, 1993a,b) examined the effect of financial development and economic growth using a number of econometric techniques, such as crosssectional, time series, panel data, and firm-level studies².

\footnotetext{
${ }^{2}$ Levine (2003) provides an excellent overview of a large body of empirical literature that suggests that financial development can robustly explain differences in economic growth across countries.
} 
By large, the empirical evidence had demonstrated that there is a positive long-run association between the indicators of financial development and economic growth. In general, all these papers suggest that a well-developed financial system is growth-enhancing, and hence, consistent with the proposition of "more finance, more growth" (Law and Singh, 2014). At the same time, focus on causality between financial development and economic growth (i.e., the finance-growth link) has spawned considerable interest among economists in recent years. Subsequently, there have been many similar studies in this regard for both developed and developing countries. While most of these studies have confirmed the existence of a causal relationship from financial development to economic growth (Menyah et al., 2014; Pradhan et al., 2013b; Hassan et al., 2011; Enisan and Olufisayo, 2009; Rousseau and Wachtel, 2000), there are a few cases where there is no evidence of causality from financial development to economic growth (Pradhan et al, 2013c; Mukhopadhyay et al., 2011; Eng and Habibullah, 2011; Stern, 1989; Lucas, 1988). Hence, the empirical studies on the relationship between financial development and economic growth do not provide any definite conclusion on the nature and direction of this relationship and currently there is no consensus among economists about the nature of this relationship. In summary, there are four possible relationships that have been emphasized in the empirical literature on the causal link between financial development and economic growth, namely the unidirectional financial development-led growth hypothesis, the unidirectional growth-led financial development hypothesis, the feedback hypotheses, and the neutrality hypothesis.

In response to the above focus on finance-growth nexus, this paper examines the nexus in the ARF countries. Specifically, we define financial development as both banking sector development and stock market development and study their impact on economic growth along 
with four other macroeconomic variables. In the next section, we highlight two bodies of literature in this regard.

\subsection{Causality between banking sector development and economic growth}

The first body of the literature examines the link between banking sector development and economic growth. In this regard, Menyah et al. (2014), Pradhan et al. (2014b), Hsueh et al. (2013), Bojanic (2012), Chaiechi (2012), Jalil et al. (2010), Kar et al. (2011), Wu et al. (2010), Abu-Bader and Abu-Qarn (2008a), Ang (2008), Naceur and Ghazouani (2007), Boulila and Trabelsi (2004), Christopoulos and Tsionas (2004), Calderon and Liu (2003), Al-Yousif (2002), Thakor (1996), Thornton (1994), Bencivenga and Smith (1991), and Greenwood and Jovanovic (1990) all demonstrated the validity of a "supply-leading" view, where unidirectional causality from banking sector development to economic growth is present. According to this view, banking sector development contributes to economic growth through two main channels: first, by raising the efficiency of capital accumulation and, in turn, the marginal productivity of capital (Goldsmith, 1969) and, second, by raising the savings rate and thus, the investment rate (McKinnon, 1973; Shaw, 1973).

In contrast to the "supply-leading" view, Kar et al. (2011), Odhiambo (2008, 2010), Panopoulou (2009), Ang and McKibbin (2007), Liang and Teng (2006), Demetriades and Hussein (1996), and Ireland (1994) claim evidence in favour of a "demand-following" view, where the causality runs from economic growth to banking sector development. According to this view, as the economy expands, demand for banking services increases, leading to the growth of these services. Studies such as those of Wolde-Rufael (2009), Lee and Chang (2009), Dritsakis and Adamopoulos (2004), Al-Yousif (2002), Craigwell et al. (2001), Ahmed and 
Ansari (1998), Greenwood and Smith (1997), and Demetriades and Hussein (1996) claim to have uncovered "feedback", whereby the causality runs in both directions. It is evident from the literature that the evidence on the direction of causality between these two variables needs more advanced statistical analysis than the literature has previously afforded it. Table 1 presents a synopsis of research on the causal nexus between banking sector development and economic growth.

\section{<< Insert Table 1 here $>>$}

\subsection{Causality between stock market development and economic growth}

A second strand of the literature examines the direction of causality between stock market development and economic growth. In this vein, Kolapo and Adaramola (2012), Colombage (2009), Enisan and Olufisayo (2009), Nieuwerburgh et al. (2006) and Tsouma (2009) support the validity of a "supply-leading" view, where unidirectional causality from stock market development to economic growth is present. By contrast, Kar et al. (2011), Panopoulou (2009), Liu and Sinclair (2008), Odhiambo (2008) Ang and McKibbin (2007), Liang and Teng (2006), and Dritsaki and Dritsaki-Bargiota (2005) present evidence in support of a "demand-following" hypothesis, where unidirectional causality from economic growth to stock market development is present. Finally, Cheng (2012), Hou and Cheng (2010), Rashid (2008), Darrat et al. (2006), Caporale et al. (2004), Hassapis and Kalyvitis (2002), Wongbangpo and Sharma (2002), Huang et al. (2000), Muradoglu et al. (2000), Masih and Masih (1999), and Nishat and Saghir (1991) demonstrate that causation runs in both directions simultaneously. Once again, the existing literature does not provide a definitive answer as to the direction of causality. Table 2 presents a 
synopsis of research on the causal nexus between stock market development and economic growth.

\section{$<$ Insert Table 2 here $>>$}

In the next section, the research questions and proposed hypotheses, as identified by the literature review, are discussed.

\section{Research Questions and Proposed Hypotheses}

This paper is not intended to be a comprehensive study of all the determinants of economic growth. Rather, it is the first of its kind to examine the nature of the relationship between economic growth, banking sector development, and stock market development, along with four other important macroeconomic variables - all within a panel vector auto-regressive model in order to detect the direction of causality between the variables. Evidently, among other things, our study melds several strands of the literature. We test the following six hypotheses:

$\checkmark \quad H_{1 A, B}:$ Banking sector development Granger-causes economic growth and vice versa.

$\mathrm{H}_{2 A}, \mathrm{~B}$ : Stock market development Granger-causes economic growth and vice versa.

$\mathrm{H}_{3 A, B}:$ A macroeconomic variable Granger-causes economic growth and vice versa.

$\checkmark \quad H_{4 A, B}$ : Banking sector development Granger-causes stock market development and vice versa.

$H_{5 A, B}$ : Banking sector development Granger-causes a macroeconomic variable and vice versa. 


\section{$\checkmark H_{6 A, B}:$ Stock market development Granger-causes a macroeconomic variable and vice versa.}

Figure 1 summarizes the proposed hypotheses, which describes the direction of possible causality among these aforementioned variables.

\section{$<<$ Insert Figure 1 here $>>$}

\section{Data Structure, Sample Selection, and Variables}

Our analysis utilizes annual time series data over the period of 1961-2012. The data are abstracted and transformed from two main sources: (i) World Development Indicators, published by the World Bank and (ii) World Investment Reports, published by the United Nations. We consider four samples of countries. The countries considered comprise the ARF-26 - a group of countries that have not been studied in this literature. ${ }^{3}$ Our first broad sample consists of the ten countries among the ARF-26 that are recognized as ARF-member countries (AMC), which includes Brunei, Burma, Cambodia, Indonesia, Laos, Malaysia, Philippines, Singapore, Thailand, and Vietnam. The second broad sample consists of the nine countries among the ARF-26 that are recognized as ARF-dialogue partner countries $(\mathrm{ADC})^{4}$ which includes Australia, Canada, China, India, Japan, New Zealand, the Korean Republic, the Russian Federation, and the United States. The third broad sample consists of the six countries among the ARF-26 that are recognized as ARF-observer countries (AOC), which includes Papua New Guinea, Mongolia, Pakistan, East

\footnotetext{
${ }^{3}$ The 26 ARF (ASEAN Regional Forum) countries include 25 member nations plus the European Union, which is represented by the President of the European Council and by the European Central Bank. The member countries are: Brunei, Burma, Cambodia, Indonesia, Laos, Malaysia, Philippines, Singapore, Thailand, Vietnam, Australia, Canada, China, the European Union, India, Japan, New Zealand, the Korean Republic, the Russian Federation, the United Sates, Papua New Guinea, Mongolia, Pakistan, East Timor, Bangladesh and Sri Lanka.

${ }^{4}$ We observe only nine countries, which are used for our analysis. The European Union, the tenth member of this group, is excluded since it is not a country.
} 
Timor, Bangladesh, and Sri Lanka. The fourth sample consists of all 26 countries (ATC) that were included in AMC, ADC, and AOC.

The variables used in the study are banking sector development (BSD), stock market development (SMD), per capita economic growth (GDP), and a set of four other macroeconomic variables (MED), namely foreign direct investment (FDI), trade openness (OPE), inflation rate (INF), and government consumption expenditure (GCE).

Banking sector development is defined as a process of improvements in the quantity, quality, and efficiency of banking services. This process involves the interaction of many activities, and consequently cannot be captured by a single measure (Pradhan et al., 2013b; Banos et al., 2011; Gries et al., 2009; Abu-Bader and Abu-Qarn, 2008b; Liang and Teng, 2006; Beck and Levine, 2004; Naceur and Ghazouani, 2007; Rousseau and Wachtel, 1998; Levine and Zervos, 1998; Gregorio and Guidotti 1995). Accordingly, the present study employs four commonly-used measures of banking sector development, namely broad money supply (BRM), claims on private sector (CLM), domestic credit provided by the banking sector (DCB), and domestic credit to the private sector (DCP).

Similarly, stock market development is defined as a process of improvements in the quantity, quality and efficiency of stock market services. It also involves the interaction of many activities and cannot be captured by a single measure (Pradhan et al., 2013a; Cheng, 2012; Kolapo and Adaramola, 2012; Kar et al., 2011; Cooray, 2010; Rousseau and Xiao, 2007; Zhu et al., 2004; Hou and Cheng, 2010; Rousseau, 2009; Darrat et al., 2006; Caporale et al., 2004; Wongbangpo and Sharma, 2002; Rousseau and Wachtel, 1998). The present study deploys four commonlyused measures of stock market development, namely market capitalization (MAC), traded stocks (TRA), turnover ratio (TUR), and the number of listed companies (NLC). 
We use the composite indicators for both BSD and SMD by using the financial indicators above and through principal component analysis (see Appendix 1 for a detailed discussion). These variables are summarized in Tables 3-5.

\section{$<$ Insert Tables 3- 5 here $>$}

The descriptive statistics of the panel data used in this study and the correlation between the variables are summarized in Tables 6 and 7, respectively.

\section{$<<$ Insert Tables 6 and 7 here >}

\section{Analytical Framework and Estimation Procedure}

The following empirical model describes the relationship between economic growth, banking sector development, stock market development, and the four other macroeconomic variables:

$$
\mathrm{GDP}=\mathrm{f}\{\mathrm{BSD}, \mathrm{SMD}, \mathrm{FDI}, \mathrm{OPE}, \mathrm{INF}, \mathrm{GCE}\}
$$

Of course, GDP is not always the dependent variable. The structural framework of all possible causal relationships is shown in Figure 2, which entertains the possibility that the direction of causation between the variables may proceed in one direction, or in both directions simultaneously.

\section{$<<$ Insert Figure 2 here $>>$}

Following the Holtz-Eakin et al. (1988) and Arellano and Bond (1991) estimation procedure, we can establish the causal nexus between the variables by employing a vector error-correction model (VECM) of the form: 


$$
\begin{aligned}
& {\left[\begin{array}{l}
\Delta \ln G D P_{i t} \\
\Delta \ln B S D_{i t} \\
\Delta \ln S M D_{i t} \\
\Delta \ln F D I_{i t} \\
\Delta \ln O P E_{i t} \\
\Delta \ln I N F_{i t} \\
\Delta \ln G C E_{i t}
\end{array}\right]=\left[\begin{array}{l}
\alpha_{1 j} \\
\alpha_{2 j} \\
\alpha_{3 j} \\
\alpha_{4 j} \\
\alpha_{5 j} \\
\alpha_{6 j} \\
\alpha_{7 j}
\end{array}\right]} \\
& +\sum_{k=1}^{q}\left[\begin{array}{l}
\beta_{11 i k}(L) \beta_{12 i k}(L) \beta_{13 i k}(L) \beta_{14 i k}(L) \beta_{15 i k}(L) \beta_{16 i k}(L) \beta_{17 i k}(L) \\
\beta_{21 i k}(L) \beta_{22 i k}(L) \beta_{23 i k}(L) \beta_{24 i k}(L) \beta_{25 i k}(L) \beta_{26 i k}(L) \beta_{27 i k}(L) \\
\beta_{31 i k}(L) \beta_{42 i k}(L) \beta_{33 i k}(L) \beta_{34 i k}(L) \beta_{35 i k}(L) \beta_{36 i k}(L) \beta_{37 i k}(L) \\
\beta_{51 i k}(L) \beta_{52 i k}(L) \beta_{53 i k}(L) \beta_{54 i k}(L) \beta_{45 i k}(L) \beta_{46 i k}(L) \beta_{47 i k}(L) \\
\beta_{61 i k}(L) \beta_{62 i k}(L) \beta_{63 i k}(L) \beta_{64 i k}(L) \beta_{65 i k}(L) \beta_{66 i k}(L) \beta_{67 i k}(L) \\
\beta_{71 i k}(L) \beta_{72 i k}(L) \beta_{73 i k}(L) \beta_{74 i k}(L) \beta_{75 i k}(L) \beta_{76 i k}(L) \beta_{77 i k}(L)
\end{array}\right]\left[\begin{array}{l}
\Delta \ln G D P_{i t-k} \\
\Delta \ln B S D_{i t-k} \\
\Delta \ln S M D_{i t-k} \\
\Delta \ln F D I_{i t-k} \\
\Delta \ln O P E_{i t-k} \\
\Delta \ln I N F_{i t-k} \\
\Delta \ln G C E_{i t-k}
\end{array}\right] \\
& +\left[\begin{array}{l}
\gamma_{1 i} E C T_{i t-1} \\
\gamma_{2 i} E C T_{i t-1} \\
\gamma_{3 i} E C T_{i t-1} \\
\gamma_{4 i} E C T_{i t-1} \\
\gamma_{5 i} E C T_{i t-1} \\
\gamma_{6 i} E C T_{i t-1} \\
\gamma_{7 i} E C T_{i t-1}
\end{array}\right]+\left[\begin{array}{l}
\varepsilon_{1 i t} \\
\varepsilon_{2 i t} \\
\varepsilon_{3 i t} \\
\varepsilon_{4 i t} \\
\varepsilon_{5 i t} \\
\varepsilon_{6 i t} \\
\varepsilon_{7 i t}
\end{array}\right]
\end{aligned}
$$

where $\Delta$ is the first difference filter $(\mathrm{I}-\mathrm{L}) ; \mathrm{i}=1, \ldots \mathrm{N} ; t=1, \ldots \mathrm{T}$; and $\xi_{j}(\mathrm{j}=1, \ldots, 7)$ are independently and normally distributed random variables for all $\mathrm{i}$ and $\mathrm{t}$, with zero means and finite heterogeneous variances $\left(\sigma_{\mathrm{i}}^{2}\right)$. The ECTs are error-correction terms that represent the longrun dynamics, while differenced variables represent the short-run dynamics that exist between the variables. The above model is meaningful only if the time series variables are integrated of order one $(I(1))^{5}$ and are cointegrated. If the variables are not cointegrated, the ECTs will be removed in the estimation process. We look for both short-run and long-run causal relationships. The short-run causal relationship is measured through F-statistics and the significance of the lagged changes in independent variables, whereas the long-run causal relationship is measured through the significance of the t-test of the lagged ECTs. However, the first procedure under

\footnotetext{
5 That is, if they achieve stationarity after being differenced once.
} 
VECM framework is to determine the unit root and the nature of cointegration among these seven variables.

\section{Empirical Results and Discussion}

\subsection{Results from the Panel Unit Root Test}

We begin our analysis with unit root test results for all the time series variables together with comments on their stationarity. The estimated results are presented in Table 8 . The results reveal that all seven variables in this study [BSD, SMD, GDP, FDI, OPE, INF, and GCE] are nonstationary at their levels. However, all variables become stationary at their first differences. Therefore, we can conclude that the time series for all the variables is integrated of order one over the period 1961-2012. This is true for all four samples that we consider (AMC, ADC, AOC, and ATC).

\section{<< Insert Table 8 here $>>$}

\subsection{Results from the Panel Co-integration Test}

After establishing the stationarity of the series by determining the order of integration, we use co-integration testing to determine if there is a long-run equilibrium relationship amongst these variables. While there are a number of tests available for use, we choose that of Pedroni (1999, 2004). The null hypothesis of no cointegration is examined, based on seven different test statistics (Pedroni, 2004), which includes four individual panel statistics [panel v-statistic, panel $\rho$-statistic, panel t-statistic (non-parametric) and panel t-statistic (parametric)] and three group statistics [group $\rho$-statistic, group t-statistic (non-parametric) and group t-statistic (parametric)]. A brief description of these test statistics are available in Appendix B. 
Table 9 reports the results of the panel cointegration from the seven test statistics of Pedroni. It can be seen that, of seven test statistics, we found two that are significant at 1-5\% level. Hence, the null hypothesis of no cointegration can be rejected. It can therefore be concluded that these variables are cointegrated, indicating the presence of a long-run equilibrium relationship between banking sector development, stock market development, per capita economic growth, and the other four macroeconomic variables, namely FDI, OPE, INF, and GCE. This finding is true for all the individual regions we examined as well as for Asia as a whole (AMC, ADC, AOC, and ATC) over the period 1961-2012.

\section{$<<$ Insert Table 9 here $>>$}

\subsection{Results from the Panel Granger Causality Test}

After establishing the status of unit root and cointegration, the next step is to check the direction of causality between them. The panel Granger causality test, based on panel VECM, is used to conduct the test. The above tests are performed via the Wald test. The results of the Granger causality tests for all the samples, are summarized in Table 10 and are presented below.

\section{$<$ Insert Table 10 here $>$}

\subsubsection{Long-Run Granger Causality Results}

The long-run results are ascertained through the statistical significance of the lagged errorcorrection term. From Table 10 one can see that when $\Delta$ GDP serves as the dependent variable, the lagged error-correction terms (ECTs) are statistically significant at the 1-5\% levels. This implies that economic growth tends to converge to its long-run equilibrium path in response to 
changes in its regressors. The significance of the $\mathrm{ECT}_{-1}$ coefficient in the $\Delta \mathrm{GDP}$ equation in each of the four panels confirm the existence of a long-run equilibrium between GDP and its determinants, namely banking sector development, stock market development, foreign direct investment, openness to trade, inflation rate, and government consumption expenditure. In other words, we can generally conclude that banking sector development, stock market development, foreign direct investment, openness to trade, inflation rate and government consumption expenditure Granger-cause economic growth in the long run. This is true for all four samples that we consider (AMC, ADC, AOC, and ATC) over the period 1961-2012. Therefore, the overall conclusion is that economic growth is key in ARF countries and largely influenced by financial development, both stock market and banking sector development, and the other four macroeconomic variables we consider. In addition to this, we also have other long-run Granger causal relationships between these variables. For ARF member countries (AMC), when $\triangle \mathrm{BSD}$ serves as the dependent variable, the lagged error-correction term is statistically significant at the $1 \%$ level. This indicates that economic growth, stock market development, foreign direct investment, openness to trade, inflation rate and government consumption expenditure Grangercause banking sector development in the long run. The long-run Granger causal relationships also exist in other cases when $\triangle \mathrm{FDI}, \triangle \mathrm{OPE}$, and $\triangle \mathrm{GCF}$ take turns to serve as the dependent variable.

For the ARF Dialogue Partner countries (ADC), when $\triangle \mathrm{OPE}$ and $\triangle \mathrm{INF}$ serve as the dependent variables, the lagged ECTs are statistically significant at the 1-5\% levels. This indicates that there are long-run Granger causal relationships when openness to trade or inflation serves as the dependent variable. 
For ARF Observer countries (AOC), when $\triangle$ FDI serves as the dependent variable, the lagged error-correction term is statistically significant at the $1 \%$ level. This indicates that economic growth, stock market development, banking sector development, openness to trade, inflation rate, and government consumption expenditure Granger-cause foreign direct investment in the long run.

For Total ARF countries (ATC), when $\triangle \mathrm{OPE}$ serves as the dependent variable, $\mathrm{ECT}_{-1}$ is statistically significant at the 5\% level. This indicates that economic growth, stock market development, banking sector development, foreign direct investment, inflation rate, and government consumption expenditure Granger-cause openness to trade in the long-run.

\subsubsection{Short-Run Granger Causality Results}

In contrast to the long-run Granger causality results, our study reveals a larger spectrum of short-run causality results between our sets of variables. These results are summarized in Table 11 and are presented below.

\section{<<Insert Table 11 here >}

For ARF Member Countries (AMC), we find the existence of bidirectional causality between economic growth and trade openness [GDP $\Leftrightarrow$ OPE], economic growth and foreign direct investment [GDP $\Leftrightarrow$ FDI], and between economic growth and government consumption expenditure [GDP $\Leftrightarrow$ GCE]. Moreover, we find unidirectional causality from banking sector development to stock market development $[\mathrm{BSD}=>\mathrm{SMD}]$, banking sector development to government consumption expenditure [BSD => GCE], stock market development to government 
consumption expenditure [SMD $=>\mathrm{GCE}$ ], economic growth to trade openness [GDP $\Rightarrow$ OPE], foreign direct investment to trade openness [FDI $=>\mathrm{OPE}]$, inflation to foreign direct investment [INF $=>$ FDI], government consumption expenditure to foreign direct investment [GCE => FDI], inflation to trade openness $[\mathrm{INF}=>\mathrm{OPE}]$, government consumption expenditure to trade openness $[\mathrm{GCE}=>\mathrm{OPE}]$, and from inflation to government consumption expenditure [INF $=>$ GCE].

For ARF Dialogue Partners Countries (ADC), we uncover bidirectional causality between banking sector development and government consumption expenditure [BSD $\Leftrightarrow$ GCE], stock market development and economic growth $[$ SMD $\Leftrightarrow$ GDP], trade openness and stock market development $[\mathrm{OPE} \longleftrightarrow$ SMD], inflation and stock market development [INF $\Leftrightarrow$ SMD], and between trade openness and government consumption expenditure [OPE $\Leftrightarrow$ GCE]. In addition, we find unidirectional causality from banking sector development to foreign direct investment $[\mathrm{BSD} \Rightarrow \mathrm{FDI}]$, banking sector development to inflation $[\mathrm{BSD} \Rightarrow \mathrm{INF}]$, stock market development to government consumption expenditure [SMD $\Rightarrow$ GCE], foreign direct investment to economic growth [FDI => GDP], economic growth to both trade openness and inflation [GDP $=>\mathrm{OPE} ; \mathrm{GDP}=>\mathrm{INF}]$, government consumption expenditure to both economic growth and inflation $[\mathrm{GCE}=>\mathrm{GDP} ; \mathrm{GCE}=>\mathrm{INF}]$, trade openness to foreign direct investment $[\mathrm{OPE}=>$ FDI], and inflation to trade openness [INF $=>$ OPE].

For ARF Observer Countries (AOC), we find the existence of bidirectional causality between economic growth and trade openness [GDP [BSD $\Leftrightarrow>I N F]$, and stock market development and foreign direct investment [SMD $\Leftrightarrow$ FDI]. Moreover, we find unidirectional causality from banking sector development to stock market development [BSD => SMD], banking sector development to economic growth [BSD $=>$ GDP], 
foreign direct investment to banking sector development [FDI $\Rightarrow$ BSD], banking sector development to government consumption expenditure $[\mathrm{BSD} \Rightarrow \mathrm{GCE}]$, stock market development to economic growth [SMD => GDP], trade openness to stock market development $[\mathrm{OPE}=>\mathrm{SMD}]$, stock market development to government consumption expenditure [SMD $=>$ GCE], government consumption expenditure to economic growth, trade openness, and inflation $[\mathrm{GCE}=>\mathrm{GDP} ; \mathrm{GCE}=>\mathrm{OPE} ; \mathrm{GCE}=>\mathrm{INF}]$, trade openness to foreign direct investment $[\mathrm{OPE}$ => FDI], and foreign direct investment to government consumption expenditure [FDI => GCE].

For ARF Total Countries (ATC), we discover the existence of bidirectional causality between inflation and banking sector development [INF $\Leftrightarrow>$ BSD], trade openness and stock market development [OPE $\Leftrightarrow$ SMD], economic growth and trade openness [GDP $\Leftrightarrow$ OPE], trade openness and foreign direct investment [OPE $<$ FDI], and between trade openness and government consumption expenditure $[\mathrm{OPE} \Leftrightarrow \mathrm{GCE}]$. Furthermore, we find unidirectional

causality from banking sector development to stock market development [BSD $\Rightarrow$ SMD], banking sector development to government consumption expenditure $[\mathrm{BSD}=>\mathrm{GCE}]$, trade openness to banking sector development [OPE $=>$ BSD], stock market development to economic growth, inflation, and government consumption expenditure [SMD $\Rightarrow$ GDP; SMD $=>$ INF; $\mathrm{SMD}=>\mathrm{GCE}$ ], foreign direct investment to economic growth [FDI $\Rightarrow$ GDP], government consumption expenditure to both foreign direct investment and inflation [GCE $\Rightarrow$ FDI; GCE $\Rightarrow$ INF], and inflation to trade openness [INF $=>\mathrm{OPE}]$.

\subsubsection{Discussions and Insights}

It should be clear that unlike much of the earlier literature, we make a clear distinction between the short-run and the long-run causal relationships. The long-run causal results depict 
the causal link between the variables in the long-run, whereas short-run causal results describe the adjustment dynamics between the variables in the short-run.

We found uniform and robust results for the long-run equilibrium relationship amongst the variables, when economic growth serves as the dependent variable. Thus, evidently, for the sake of stimulating long-run economic growth, banking sector development, stock market development, foreign direct investment, and openness to trade should be encouraged in the ARF countries.

For short-run causal relationships, we find remarkable variations in results which are nonetheless congruent with earlier work in the different strands of this literature. We highlight some of these short-run results below.

Firstly, our result that banking sector development Granger causes economic growth, lends support to the "supply-leading hypothesis (SLH)". This result appears in two of our samples (ADC and AOC) and is consistent with the findings of Menyah et al. (2014), Pradhan et al. (2014b), Pradhan et al. (2013a), Hsueh et al. (2013), Bojanic (2012), Chaiechi (2012), Akinlo and Akinlo (2009), Nowbusting (2009), Tsouma (2009), Enisan and Olufisayo (2009), Colombage (2009), Deb and Mukherjee (2008), Shahbaz et al. (2008), Nieuwerburgh et al. (2006), and Levine and Zervos (1998).

Secondly, our result that stock market development Granger causes economic growth, lending support to the "supply-leading hypothesis (SLH)", appears in all four samples of our study and is consistent with the findings of Pradhan et al. (2013a), Kolapo and Adaramola (2012), Tsouma (2009), Enisan and Olufisayo (2009), Colombage (2009), Deb and Mukherjee (2008), and Nieuwerburgh et al. (2006). 
Thirdly, our findings that macroeconomic determinants (FDI and GCE) Granger cause economic growth, lend support to the "supply-leading hypothesis (SLH)" view. These results hold true in all four samples and are consistent with the findings of Pradhan et al. (2014a), Abdelhafidh (2013), Lean and Tan (2011), Tang and Wang (2011), Lee (2010), and Zhang (2001).

Fourthly, we find banking sector development and stock market development Granger cause each other, which supports the prevalence of the feedback hypothesis (FBH). This is true for all four samples in our study and is consistent with the earlier findings of Pradhan et al. (2014a), Cheng (2012), Hou and Cheng (2010), Beck and Levine (2004), and Levine and Zervos (1998).

In addition, there are cases where both banking sector development and stock market development Granger cause macroeconomic determinants and vice versa. For instance, in AMC, BSD Granger causes INF in most of our samples (see Table 11). This supports the findings of Rashid (2008), Darrat et al (2006), Bilson et al. (2001), and Garcia and Liu (1999).

\subsubsection{Results from Generalized Impulse Response Functions}

The Holtz-Eakin et al. (1988) and Arellano and Bond (1991) estimation procedure is one way of checking the Granger causality amongst the variables used in the present study. However, this estimation procedure does not provide much information on how each variable responds to innovations in other variables, or whether the shock is permanent or not. This shortcoming can be overcome by using the generalized impulse response function (GIRF) as in Koop et al. (1996) and Pesaran and Shin (1998). The GIRF has an advantage in that it is insensitive to the ordering of the variables in the VAR system. The GIRF approach overcomes the originality problem inherent in traditional out-of-sample Granger causality tests. The results of the Granger causality 
test do not suggest that an unexpected change, i.e. shock, does not affect the changes in financial development. Therefore, the GRIF is used to discover which variable takes precedence over the other. That means that the GIRF indicates how persistent and strong these effects are, therefore to trace the effect of a one-off shock to one of the innovations on the current and future values of the endogenous variables. In this context, the mutual impacts of banking sector development, stock market development, a set of macroeconomic variables (FDI, OPE, INF and GCE), and economic growth are presented in Figures 3-6. The GIRFs ${ }^{6}$ are plotted out to 10 periods after the shocks.

\section{$<$ Insert Figures 3-6 here >>}

While the years after the impulse shocks are shown on the horizontal axis, the vertical axis measures the magnitude of the response, scaled in such a way that 1.0 equals 1 standard deviation. The significance is determined by the use of confidence intervals representing \pm 2 standard deviation (Runkle, 1987). A Monte Carlo simulation with 1000 replications is used to obtain the error brands. At points where the confidence brands do not straddle the line at zero, the impulse response is considered to be statistically different from zero at the $5 \%$ level of significance or less $(\mathrm{p} \leq 0)$. Figures 3-6 reflect that an unexpected positive change (i.e., shock) in economic growth has a positive and significant initial impact effect on own economic growth. This effect then diminishes over the next period and becomes negative over a horizon of the next two periods after the shock at which economic growth returns to steady state or equilibrium. This 'own' effect to a shock is consistent with the cycling process often found in banking sector

\footnotetext{
${ }^{6}$ Before using the results of generalized impulse responses, the procedure is to perform the log-likelihood ratio (LR) test to determine whether the shocks are contemporaneously correlated in the individual equations that make up the VAR. This suggests that the assumption that all off-diagonal elements in the covariance matrix are zero is strongly rejected, and we hence use the GIRFs in our analysis (see, for instance, Lee et al., 2013).
} 
development, stock market development, and other macroeconomic determinants. In fact, a shock to both banking sector development and stock market development are positive and significant after two periods before the effects of the shock completely wear off. Therefore, both banking sector development and stock market development exhibit cycling behavior and persistence to shocks.

An advantage of utilizing the impulse response analysis within a vector autoregressive framework is that it allows for the treatment of the responses to shocks, known as a 'cross effect'. Hence, GIRFs offer an additional support into how shocks to banking sector development and stock market development can affect and be affected by economic growth and other macroeconomic variables.

Meaningful GIRFs are considered as an out-of-sample Granger causality test, and hence, the discussions on the long-run Granger causality could be applied in this part as well. Since the shocks are both negative and positive events, the economic application for the planners are to rebalance their financial flows and macroeconomic determinants. For instance, if the government brings a sudden change to financial markets (say through money supply, market capitalization of traded stocks, or turnover ratio), based on our empirical results, then the change affects the economy in terms of banking sector development, stock market development, economic growth, and the other macroeconomic variables we consider, both in the short-run and long-run.

\section{Conclusion and Policy Implications}

Understanding the policy implications of the nexus between banking sector development, stock market development, economic growth, and other macroeconomic variables is of great importance in the field of development economics (Cheng, 2012; Boulila and Trabelsi, 2004). 
Still, much needs to be learned about the various connections among these four sets of variables. Earlier studies examine the causal link between two variables. In contrast, our study looks at the causal relationship between all the variables. That is, the causal link between two variables is considered in the presence of the remaining variables.

This study finds that banking sector development, stock market development, economic growth, and four key macroeconomic variables are cointegrated in the ARF countries. Importantly, we find that banking sector development and stock market development, as well as other macroeconomic variables, matter in the determination of long-run economic growth although the set of statistically significant independent variables varies by sample due to heterogeneity of the countries within each panel. Our results carry three policy implications:

i) With regard to the banking sector development-economic growth nexus: In order to promote economic growth, attention must be paid to policies that promote banking sector development. This, in turn, calls for an efficient allocation of financial resources combined with sound regulation of the banking system. A sound banking system instills confidence among the savers so that resources can be effectively mobilized to increase productivity in the economy. The banking system should be simplified and banking fees should be reduced for qualifying clients, so that the barriers to entry of the banking sector is lowered, making banking activities more accessible to that part of a country's population that are currently excluded from engaging in banking and financial transactions. In addition, the products of the banking system should be diversified in such a way that non-banking financial companies and non-financial institutions can enter the banking sector (as advocated in Marcelin and Mathur, 2014).

ii) With regard to the stock market development-economic growth nexus: To promote economic growth, a well-developed stock market will likely be necessary for these ARF 
countries, including the future provision of stock market development. A credible and reliable stock market system is indispensable to ensure the smooth-functioning of the financial system and to increase the productivity of the economy, congruent with the arguments presented in Yartey (2008) and Levine (1991). A well-developed stock market will facilitate the raising of debt and equity capital for investment by firms, thereby further enhancing economic growth and attracting foreign direct investment by multi-national corporations.

iii) With regard to the MED-economic growth nexus: In order to facilitate economic growth, macroeconomic development is solely desirable in these ARF countries. For instance, attracting foreign direct investment and promoting trade openness can facilitate further investment and easier means of raising capital to support the activities of stock markets and banks, which will lead to increased economic activity (as also argued in Herwartz and Walle, 2014). 


\section{Appendix A: Principal Component Analysis}

Modelling various indicators of banking sector development and stock market development in the same equation would lead to multicollinearity. Thus, we combine these indicators together to create an index of banking sector development and stock market development. We use principal component analysis (PCA), which is based on a linear transformation of the variables so that they are orthogonal to each other (Lewis-Beck, 1994). It is ideally suited because it maximizes the variance, rather than minimizing the least square distance. In brief, PCA transforms the data into new variables (i.e., the principal components) that are not correlated.

The concept of PCA is to construct indexes similar to ours is well-documented in several papers (for example, Menyah et al., 2014; Herwartz and Walle, 2014; Coban and Topcu, 2013; Pradhan et al., 2013c; Murthy and Kalsie, 2013; Huang, 2010; Gries et al., 2009; Saci and Holden, 2008; Ang and McKibbin, 2007; Shih et al., 2007; Fritz, 1984). ${ }^{7}$ To be clear, PCA is a special case of the more general method of factor analysis. The PCA entails a few structured steps, including the construction of a data matrix, creation of standardized variables, calculation of a correlation matrix, determination of eigen values (to rank principal components) and eigenvectors, selection of PCs (based on stopping rules), and the interpretation of results (Hosseini and Kaneko, 2011, 2012). The intent behind PCA is to transform the original set of variables into a smaller set of linear combinations that account for most of the variance of the original set. The aim is to construct from a set of variables, $X_{j}$ 's $(j=1,2, \ldots, n)$ that are new variables $\left(P_{i}\right)$ called 'principal components', which are linear combinations of the $X$ 's. Representing it mathematically,

\footnotetext{
${ }^{7}$ Manly (1994), Sharma (1996), Joliffe (2002), Hosseini and Kaneko (2011, 2012), Pradhan et al. (2013b) provide the procedural details on the use of PCA.
} 


$$
\begin{gathered}
P_{1}=a_{11} X_{1}+\ldots \ldots \ldots \ldots \ldots+a_{1 n} X_{n} \\
\cdot \\
P_{m}=a_{m 1} X_{1}+\ldots \ldots \ldots \ldots .+a_{m n} X_{n}
\end{gathered}
$$

which can be re-written as

$$
P=\sum_{i=1}^{n} a_{i j} X_{i} \quad \text { for }(j=1,2, \ldots . m)
$$

where $P=\left[P_{1}, P_{2}, \ldots, P_{m}\right]$ are principal components; $\mathrm{A}=\left[a_{i j}\right]$ for $i=(1,2, \ldots, \mathrm{m})$; and $j=(1,2, \ldots$, n) are component loadings; and $X=\left[X_{1}, X_{2}, \ldots, X_{n}\right]$ are original variables. The component loadings are the weights showing the variance contribution of principal components to variables. Since the principal components are selected orthogonal to each other, $a_{i j}$ weights are proportional to the correlation coefficient between variables and principal components.

The first principal component $\left(P_{1}\right)$ is determined as the linear combination of $X_{1}, X_{2}, \ldots, X_{n}$, provided that the variance contribution is at a maximum. The second principal component $\left(P_{2}\right)$, independent from the first principal component, is determined so as to provide a maximum contribution to the total variance left after the variance explained by the first principal component. Analogously, the third and the other principal components are determined as to provide the maximum contribution to the remaining variance and are independent from each other. The aim here is to determine $a_{i j}$ coefficients, providing the linear combinations of variables based on the specified conditions.

It should be noted here that the method of principal components could be applied by using the original values of the $X_{j}$ 's, by their deviations from their means, or by the standardized variables. The present study, however, adopts the latter procedure, as it is assumed to be more 
general and can be applied to variables measured in different units. It is important to note that the values of the principal components will be different depending on the way in which the variables are used (original values, deviations, or standardized values). The coefficients $a$ 's, called loadings, are chosen in such a way that the constructed principal components satisfy two conditions: (a) principal components are uncorrelated (orthogonal), and (b) the first principal component $P_{l}$ absorbs and accounts for the maximum possible proportion of total variation in the set of all $X$ 's. Furthermore, the principal component absorbs the maximum of the remaining variation in the $X$ 's, after allowing for the variation accounted for by the first principal component, and so on. There are different rules to define a high magnitude, known as stopping rules. Here, variance explained criteria are implemented based on the rule of keeping enough principal components to account for $90 \%$ of the variation (see, for instance, Murthy and Kalsie, 2013; Hosseini and Kaneko, 2011, 2011; Joliffe, 2002; Jackson, 1991; Wold, 1978).

Thus, PCA examines the statistical correlations across the different variables, and assigns the largest weights to the indicators of banking sector development and stock market development, most correlated with the other indicators in the dataset (Creane and Goyal, 2004). Intuitively, PCA tries to uncover the common statistical characteristics across the various indicators in order to combine them into a composite index of banking sector development and a composite index of stock market development.

The following equation is used to construct $\mathrm{BSD}$, our composite index for banking sector development:

$$
B S D=\sum_{i=1}^{4} w_{i j} \frac{X_{i j}}{S d\left(X_{i}\right)}
$$


where BSD is our composite index for banking sector development, $S d$ is standard deviation, $X_{i j}$ is the $i^{\text {th }}$ variable in the $j^{\text {th }}$ year; and $w_{i j}$ is factor loading, as derived by PCA. Thus, BSD captures the four indicators we mentioned earlier, which are summarized under Table 3. The index is calculated for each country and for each year of our study.

An analogous equation may be used to create SMD, our composite index for stock market development, using the four indicators that are summarized under Table 4. 


\section{Appendix B: Panel Unit Root Test and Panel Cointegration Test}

\section{B. 1 Unit Root Test for the Panel Data}

One of the primary reasons for the utilization of a panel of cross section units for unit root tests is to increase the statistical power of their univariate counterparts. The traditional Augmented Dickey-Fuller (ADF) test of unit root is characterized by having a low power in rejecting the null hypothesis of no stationarity of the series, especially for short-spanned data. On the contrary, recent developments in the econometrics literature suggest that panel based unit root tests have higher power than the unit root tests based on individual time series analysis. Panel data techniques are also preferable because of their weak restrictions; indeed, they capture both country-specific effects and heterogeneity in the direction and magnitude of the parameters across the panel. Furthermore, these techniques allow the model to be selected with a high degree of flexibility, proposing a relatively wide range of alternative specifications, from models with no constant and no trends to models with a constant and deterministic trend. Within each model, there is the possibility of testing for common time effects.

The unit root test examines the order of integration, where the time series variable attains stationarity. We deploy the Levine-Lin-Chu (LLC: Levine et al., 2002) test for determining the order of integration. The test is based on the principles of the conventional ADF test. The LLC test allows for heterogeneity of the intercepts across members of the panel. It is applied by averaging the individual ADF t- statistics across cross-section units. The test proceeds with the estimation of the following equation:

$$
\Delta Y_{t}=\mu_{i}+\tau_{i} Y_{i t-1}+\sum_{j=1}^{p_{i}} \beta_{i j} \Delta Y_{i t-j}+\lambda_{i} t+\varepsilon_{i t}
$$


where

$\mathrm{i}=1,2,3, \ldots, \mathrm{N} ; \mathrm{t}=1,2,3, \ldots, \mathrm{T}$;

$\mathrm{Y}_{\mathrm{it}}$ is the series for country $\mathrm{i}$ in the panel over period $\mathrm{t}$;

$\mathrm{p}_{\mathrm{i}}$ is the number of lags selected for the ADF regression;

$\Delta$ is the first difference filter $(\mathrm{I}-\mathrm{L})$;

and $\varepsilon_{i t}$ are independently and normally distributed random variables for all $\mathrm{i}$ and $\mathrm{t}$ with zero means and finite heterogeneous variances $\left(\sigma_{\mathrm{i}}^{2}\right)$.

The LLC test considers the coefficients of the autoregressive term as homogenous across all individuals, i.e., $\tau_{\mathrm{i}}=\tau$ for all $\mathrm{i}$. It tests the null hypothesis that each individual in the panel has integrated time series, i.e.,

$\mathrm{H}_{0}: \tau_{\mathrm{i}}=\tau=0$ for all $\mathrm{i}$ against an alternative $\mathrm{H}_{\mathrm{A}}: \tau_{\mathrm{i}}=\tau<0$ for all $\mathrm{i}$.

Furthermore, the test considers pooling the cross-section time series data. It is based on the following t-statistics:

$$
t_{y}^{*}=\frac{\hat{\tau}}{\text { s.e. }(\hat{\tau})}
$$

Here, in the LLC test, $\tau$ is restricted by being kept identical across regions under both the null and alternative hypotheses.

\section{B. 2 Cointegration Test for the Panel Data}

The technique 'cointegration', introduced by Granger (1988), is relevant to the problem of the determination of a long-run relationship between variables. The basic idea behind cointegration is simple. If the difference between two non-stationary series is itself stationary, 
then the two series are said to be cointegrated. If two or more series are cointegrated, it is possible to interpret the variables in these series as being in a long-run equilibrium relationship. On the other hand, the lack of cointegration, suggests that the variables have no long-run relationship; i.e., in principle they can move arbitrarily far away from each other.

When a collection of time-series observations becomes stationary, only after being firstdifferenced, the individual time series may have linear combinations that are stationary without differencing. Such collections of series are known to be cointegrated (Granger, 1988). If the variables are integrated of 'order one' (i.e. I (1)), we can employ cointegration technique in order to establish whether there is any long-run equilibrium relationship among the set of such possibly 'integrated' variables. The Pedroni's panel cointegration method (Pedroni, 2000) is used to determine the existence of cointegration among these three series. The technique starts with the following regression equation.

$$
G D P_{i t}=\beta_{0 i}+\beta_{1 i} t+\beta_{2 i} B S D_{i t}+\beta_{3 i} S M D_{i t}+\beta_{4 i} M E D_{i t}+\varepsilon_{i t} \text { and } \varepsilon_{i t}=\eta_{i} \varepsilon_{i t-1}+\xi_{i t}
$$

where

$$
\mathrm{i}=1,2,3, \ldots ., \mathrm{N} ; \text { and } \mathrm{t}=1,2,3, \ldots, \mathrm{T} \text {. }
$$

$\beta_{0 \mathrm{i}}$ is the member- specific intercept, or fixed- effects parameter, that is allowed to vary across individual cross-sectional units. The $\beta_{1 \mathrm{i}}$ is a deterministic time trend specific to individual countries in the panel. The slope coefficients, $\beta_{2 \mathrm{i}}$ and $\beta_{3 \mathrm{i}}$, may vary from one individual to another, allowing the cointegrating vectors to be heterogeneous across countries.

There are seven different statistics, as proposed by Pedroni (2000), for the cointegration test in the panel data setting. Of the seven statistics, the first four are known as panel cointegration statistics, which are within-dimension statistics, while the last three are known as group mean 
panel cointegrating statistics, which are between-dimension statistics. Their levels are based on the way the autoregressive coefficients are manipulated to arrive at the final statistic. There are basically five steps to obtain these cointegration statistics. The mathematical exposition and the asymptotic distributions of these panel cointegration statistics are contained in Pedroni (1999). Under an appropriate standardization, based on the moments of the vector of Brownian motion function, these statistics are distributed as standard normal. Accordingly, the null of no cointegration is then tested, based on the above description of standard normal distribution. The null hypothesis and alternative hypothesis of no cointegration of the pooled, within-dimension, estimation are as follows:

$\mathrm{H}_{0}: \eta_{\mathrm{i}}=1 \forall i$ against an alternative hypothesis $\mathrm{H}_{\mathrm{A}}: \eta_{\mathrm{i}}=\eta<1 \forall i$

where the within-dimensional estimation assumes a common value for $\eta_{i}=\eta$

On the contrary, the group means panel cointegration statistics (i.e., pooled betweendimension) test the following hypothesis of no cointegration:

$\mathrm{H}_{0}: \eta_{\mathrm{i}}=1 \forall i$ against an alternative hypothesis $\mathrm{H}_{\mathrm{A}}: \eta_{\mathrm{i}}<1 \forall i$

where, under the alternative hypothesis, the between-dimensional estimation does not presume a common value for $\eta_{i}=\eta$.

This allows an additional source of possible heterogeneity across individual country members of the panel. These statistics diverge to negative infinity under the alternative hypothesis. As a result, the left tail of the normal distribution is usually employed here to reject the null hypothesis. 


\section{References}

Abdelhafidh, S. (2013). Potential Financing Sources of Investment and Economic Growth in North African Countries: A Causality Analysis. Journal of Policy Modelling, Vol. 35, No. 1, 150-169.

Abu-Bader, S. and Abu-Qarn, A. S. (2008b). Financial Development and Economic Growth: Empirical Evidence from Six MENA Countries. Review of Development Economics, Vol. 12, No. 4, pp. 803-817.

Aghion, P., Howit, P. and Mayer-Foulkes, D. (2005). The Effect of Financial Development on Convergence: Theory and Evidence. Quarterly Journal of Economics, Vol. 120, No. 1, pp. 173222.

Ahmed, S. M. and Ansari, M. I. (1998). Financial Sector Development and Economic Growth: The South-Asian Experience. Journal of Asian Economics, Vol. 9, No. 3, pp. 503-517.

Akinlo A. E. and Akinlo O. O. (2009). Stock Market Development and Economic Growth: Evidence from Seven Sub-Sahara African Countries. Journal of Economics and Business, Vol. 61, No. 2, pp. 162-171.

Allen, F., Gu, X. and Kowalewski, O. (2012). Financial Crisis, Structure and Reform. Journal of Banking and Finance, Vol. 36, No. 11, pp. 2960-2973.

Al-Yousif, Y. K. (2002). Financial Development and Economic Growth: Another Look at the Evidence from Developing Countries. Review of Financial Economics, Vol. 11, No. 2, pp. 131150.

Ang, J. B. (2008a). Survey of Recent Developments in the Literature of Finance and Growth. Journal of Economic Surveys, Vol. 22, No. 3, pp. 536-576.

Ang, J. B. (2008b). What are the Mechanisms linking Financial Development and Economic Growth in Malaysia? Economic Modelling, Vol. 25, No. 1, pp. 38-53.

Ang, J. B. and McKibbin (2007). Financial Liberalization, Financial Sector Development and Growth: Evidence from Malaysia? Journal of Development Economics, Vol. 84, No.1, pp. 215233.

Arellano, M. and Bond, S. (1991). Some Tests of Specification for Panel Data: Monte Carlo Evidence and An Application to Employment Fluctuations. Review of Economic Studies, Vol. 58, No. 2, pp. 277-297.

Bangake, C. and Eggoh, J. C. (2011). Further Evidence on Finance-Growth Causality: A Panel Data Analysis. Economic Systems, Vol. 35, No. 2, pp. 176-188.

Banos, J. L., Crouzille, C. M., Nys, E. and Sauviat, A. (2011). Banking Industry Structure and Economic Activities: A Regional Approach for the Philippines. Philippines Management Review, Vol. 18, No. 1, pp. 97-113.

Beck, T. and Levine, R. (2004). Stock Markets, Banks, and Growth: Panel Evidence. Journal of Banking and Finance, Vol. 28, No. 3, pp. 423-442.

Beck, T., Levine, R. and Loayza, N. (2000). Finance and Source of Growth. Journal of Financial Economics, Vol. 58, Nos. 1-2, pp. 261- 300.

Bencivenga, V. R. and Smith, B. D. (1991). Financial Intermediation and Endogenous Growth. Review of Economic Studies, Vol. 58, No. 2, pp. 195-209.

Bencivenga, V. R., Smith, B. D. and Starr, R. M. (1995). Transaction Costs, Technological Choice, Endogenous Growth. Journal of Economic Theory, Vol. 67, No. 1, pp. 53-117.

Berthelemy, J. C. and Varoudakis, A. (1996). Economic Growth, Convergence Clubs, and the Role of Financial Development. Oxford Economic Papers, Vol. 48, No. 2, pp. 300-328. 
Bilson, C. M., Brailsford, T. J. And Hooper, V. J. (2001). Selecting Macroeconomic Variables as Explanatory Factors of Emerging Stock Market Returns. Pacific-Basin Finance Journal, Vol. 9, No. 4, pp. 401-426.

Blackburn, K. and Hung, V. T. Y. (1998). A Theory of Growth, Financial Development and Trade. Economica, Vol. 65, No. 257, pp. 107-124.

Bojanic, A. N. (2012). The Impact of Financial Development and Trade on the Economic Growth of Bolivia. Journal of Applied Economics, Vol. 15, No. 1, pp. 51-70.

Boulila, G. and Trabelsi, M. (2004). Financial Development and Long Run Growth: Evidence from Tunisia: 1962-1997. Savings and Development, Vol. 28, No. 3, pp. 289-314.

Calderon, C. and Liu, L. (2003). The Direction of Causality between Financial Development and Economic Growth. Journal of Development Economics, Vol. 72, No. 1, pp. 321- 334.

Caporale, G. M., Howells, P. G. and Soliman, A. M. (2004). Stock Market Development and Economic Growth: The Causal Linkage. Journal of Economic Development, Vol. 29, No. 1, pp. 33-50.

Castaneda, G. (2006). Economic Growth and Concentrated Ownership in Stock Markets. Journal of Economic Behavior and Organization. Vol. 59, No. 1, pp. 249-286.

Chaiechi, T. (2012). Financial Development Shocks and Contemporaneous Feedback Effect on Key Macroeconomic Indicators: A post Keynesian Time Series Analysis. Economic Modelling, Vol. 29, No. 2, pp. 487-501.

Cheng, S. (2012). Substitution or complementary effects between banking and stock markets: Evidence from financial openness in Taiwan. Journal of International Financial Markets, Institutions and Money, 2012, Vol. 22, No. 3, pp. 508-520.

Choe, C. and Moosa, I. A. (1999). Financial System and Economic Growth: The Korean Experience. World Development, Vol. 27, No. 6, pp. 1069-1082.

Choong, C. K., Yusop, Z., Law, S. H. and Venus, L. K. S. (2003). Financial Development and Economic Growth in Malaysia: The Stock Market Prospective. Economic Working Paper, achieve at WUSTL-Macroeconomics.

Chow, W. W. and Fung, M. K. (2011). Financial Development and Growth: A Clustering and Causality Analysis. Journal of International Trade and Economic Development, Vol. 35, No. 3, pp. 1-24.

Christopoulos, D. K. and Tsionas, E. G. (2004). Financial Development and Economic Growth: Evidence from Panel Unit Root and Cointegration Tests. Journal of Development Economics, Vol. 73, pp. 55-74.

Cole, R. A., Moshirian, F. and Wu, Q. (2008). Bank Stock Returns and Economic Growth. Journal of Banking and Finance, Vol. 32, No. 6. pp. 995-1007.

Colombage, S. R. N. (2009). Financial Markets and Economic Performances: Empirical Evidence from Five Industrialized Countries. Research in International Business and Finance, Vol. 23, No. 3, pp. 339-348.

Cooray, A. (2010). Do Stock Markets Lead to Economic Growth? Journal of Policy Modeling, Vol. 32, No. 4, pp. 448-460.

Craigwell, R., Downes, D. and Howard, M. (2001). The Finance-Growth Nexus: A Multivariate VAR Analysis of a Small Open Economy. Savings and Development, Vol. 25, No.2, pp. 209223.

Darrat, A. F., Elkhal, K. and McCallum, B. (2006). Finance and Macroeconomic Performance: Some Evidence from Emerging Markets. Emerging Markets Finance and Trade, Vol. 42, No. 3, pp. 528. 
Deb, S.G. and Mukherjee, J. (2008). Does Stock Market Development Cause Economic Growth? Time Series Analysis for Indian Economy. International Research Journal of Finance and Economics, Vol. 21, pp. 142-149

Demetriades P. O. and Luintel, K. B.(1996). Financial Development, Economic Growth and Banking Sector Controls: Evidence from India. The Economic Journal, Vol. 106, No. 435, pp. 359-374.

Demirguc-kunt, A. and Levine, R. (2009). Finance and Inequality: Theory and Evidence. Policy Research Working Paper Series, No. 4967. The World Bank, Washington DC.

Drake, P. J. (1980). Money, Finance and Development. Halsted Press, New York.

Dritsaki, C. and Dritsaki-bargiota, M. (2005). The Causal Relationship between Stock, Credit Market and Economic Development: An Empirical Evidence of Greece. Economic Change and Restructuring, Vol. 38, No. 1, pp. 113-127.

Dritsakis, N. and Adamopoulos, A. (2004). Financial Development and Economic Growth in Greece: An Empirical Investigation with Granger Causality Analysis. International Economic Journal, Vol. 18, No. 4, pp. 547-559.

Eng, Y., and Habibullah M. S. (2011). Financial Development and Economic Growth Nexus: Another look at the Panel Evidence from Different Geographical Regions. Bank and Bank Systems, Vol. 6, No. 1, pp. 62-71.

Enisan, A. A. and Olufisayo, A.O. (2009). Stock Market Development and Economic Growth: Evidence from Seven Sub-Saharan African Countries. Journal of Economics and Business, Vol. 61, No. 2, pp. 162-171.

Esso, L. J. (2010). Re-examining the Finance-Growth Nexus: Structural Break, Threshold Cointegration and Causality Evidence from the ECOWAS. Journal of Economic Development, Vol. 35, No. 3, pp. 57-79.

Fase, M. M. G. and Abma, R. C. N. (2003). Financial Environment and Economic Growth in Selected Asian Countries. Journal of Asian Economics, Vol. 14, No. 1, pp. 11-21.

Fink, G., Haiss, P. and Vuksic, G. (2009). Contribution of Financial Market Segments at Different Stages of Developmnet: Transition, Cohesion and Mature Economies Compared. Journal of Financial Stability, Vol. 5, No. 4, pp. 431-455.

Fink, G., Haiss, P. and Vuksic, G. (2006). Importance of Financial Sectors for Growth in Accession Countries. In (Liebscher, K., Christ, J., Mooslechner, P., and Ritzberger-Grunwald, D. (Eds.), Financial Developmnet, Integration and Stability, pp. 154-185. Edward Elgar, Cheltenham.

Fritz, R. G. (1984). Time Series Evidence of the Causal Relationship between Financial Deepening and Economic Development. Journal of Economic Development, Vol. 9, No. 1, pp. 91-111.

Fung, M. K. (2009). Financial Development and Economic Growth: Convergence or Divergence? Journal of International Money and Finance, Vol. 28, No. 1, pp. 56-67.

Garcia, V. F. and Liu, L. (1999). Macroeconomic Determinants of Stock Market Development. Journal of Applied Economics, Vol. 11, No. 1, pp. 29-59.

Gimet, C. and Lagoarde-Segot, T. (2011). Financial Sector Development and Access to Finance. Does Size Say It All? Emerging Market Review, Vol. 13, No. 3, pp. 294-312.

Gjerde, O. and Saettem, F. (1999). Causal Relations among Stock Returns and Macroeconomic Variables in a Small, Open Economy. Journal of International Financial Markets, Institutions and Money, Vol. 9, No. 1, pp. 61-74.

Graff, M. (2003). Finance Development and Economic Growth in Corporatist and Liberal Market Economies. Emerging Market Finance \& Trade, Vol. 39, No. 2, pp. 47- 69. 
Granger C. W. J. (1988). Some Recent Developments in a Concept of Causality. Journal of Econometrics, Vol. 39, Nos. 1-2, pp. 199-211.

Greenwood, J. and Bruce, S. (1997). Financial Markets in Development, and the Development of Financial Markets. Journal of Economic Dynamics and Control, Vol. 21, No. 2, pp. 145- 181.

Greenwood, J. and Jovanovic, B. (1990). Financial Development, Growth, and the Distribution of Income. Journal of Political Economy, Vol. 98, No. 5, pp. 1076-1107.

Greenwood, J. and Smith, B. (1997). Financial Markets in Development, and the Development of Financial Markets. Journal of Economic Dynamics and Control, Vol. 21, No. 1, pp. 145-181.

Gregorio, J. D. and Guidotti, P. E. (1995). Financial Development and Economic Growth. World Development, Vol. 23, No. 3, pp. 433-448.

Gries, T., Kraft, M. and Meierrieks, D. (2009). Linkages between Financial Deepening, Trade Openness, and Economic Development: Causality Evidence from Sub-Saharan Africa. World Development, Vol. 37, No. 12, pp. 1849-1860.

Hassan, K. M., Sanchez, B. and Yu, J. (2011). Financial Development and Economic Growth: New Evidence from Panel Data. The Quarterly Review of Economics and Finance, Vol. 51, No. 1, pp. 88-104.

Hassapis, C. and Kalyvitis, S. (2002). Investigating the Links between Growth and Stock Price Changes with Empirical Evidence from the G7 Economies. Quarterly Review of Economics and Finance, Vol. 42, No. 3, pp. 543-575.

Herwartz, H. and Walle, Y. M. (2014). Determinants of the Link between Financial and Economic Developmnet: Evidence from a Functional Coefficient Model. Economic Modelling, Vol. 37, No.2, pp. 417-427.

Holtz- Eakin, D., Newey, W. and Rosen, H. S. (1988). Estimating Vector Auto Regressions with Panel Data. Econometrica, Vol. 56, No. 6, pp. 1371-1395.

Hosseini, H. M. and Kaneko, S. (2012). Causality between Pillars of Sustainable Development: Global Stylized Facts or Regional Phenomena. Ecological Indicators, Vol. 14, No. 1, pp. 197201.

Hosseini, H.M. and Kaneko, S. (2011). Dynamics Sustainability Assessment of Countries at the Macro Level: A Principal Component Analysis, Ecological Indicators, Vol. 11, No. 3, pp. 811823.

Hou, H. and Cheng, S. Y. (2010). The Roles of Stock Market in the Finance-Growth Nexus: Time Series Cointegration and Causality Evidence from Taiwan. Applied Financial Economics, Vol. 20, No. 12, pp. 975-981.

Hsueh, S., Hu, Y. and Tu, C. (2013). Economic Growth and Financial Development in Asian Countries: A Bootstrap Panel Granger Causality Analysis. Economic Modelling, Vol. 32, No. 3, pp. 294-301.

Huang, B., Yang, C. and Hu, J. W. (2000). Causality and Cointegration of Stock Markets among the United States, Japan, and the South China Growth Triangle. International Review of Financial Analysis, Vol. 9, No. 3, pp. 281-297.

IMF (2005). Indicators of Financial Structure, Development, and Soundness. Chapter 2. Online available at: http://www.imf.org/external/pubs/ft/fsa/eng/pdf/ch02.pdf.

Ireland, P. N. (1994). Money and Growth: An Alternative Approach. American Economic Review, Vol. 84, No. 1, pp. 47-65.

Jackson, J. E. (1991). A User's Gide to Principal Components. Wiley-Interscience, New York. 
Jalil, A., Feridun, M. and Ma, Y. (2010). Finance-Growth Nexus in China Revisited: New Evidence from Principal Components and ARDL Bounds Tests. International Review of Economics and Finance, Vol. 19, No. 2, pp. 189-195.

Jung, W. S. (1986). Financial Development and Economic Growth: International Evidence. Economic Development and Cultural Change, Vol. 34, No. 2, pp. 336-346.

Kar, M., Nazlioglu, S. and Agir, H. (2011). Financial Development and Economic Growth Nexus in the MENA Countries: Bootstrap Panel Granger Causality Analysis. Economic Modelling, Vol. 28, Nos. 1-2, pp. 685-693.

Khan K. N. (2004). Inflation and Stock Market Performance: A Case Study for Pakistan. Savings and Development, Vol. 28, No. 1, pp. 87-101.

King, R. and Levine, R. (1993a). Finance and Growth: Schumpeter Might be Right. The Quarterly Journal of Economics, Vo. 108, No. 3, pp. 717-737.

King, R. and Levine, R. (1993b). Finance, Entrepreneurship and Economic Growth: Theory and Evidence. Journal of Monetary Economics, Vo. 32, No. 3, pp. 513-542.

Kolapo, F. T. and Adaramola, A. O. (2012). The Impact of the Nigerian Capital Market on Economic Growth (1990-2010). International Journal of Developing Societies, Vol. 1, No. 1, pp. 11-19.

Koop, G., Pesaran, M. H. and Potter, S. M. (1996). Impulse Response Analysis in Non-linear Multivariate Models. Journal of Econometrics, Vol. 74, No. 1, pp. 119-147.

Kwon, C. S. and Shin, T. S. (1999). Cointegration and Causality between Macroeconomic Variables and Stock Market Returns. Global Finance Journal, Vol. 10, No. 1, pp. 71-81.

Law, S. H. and Singh, N. (2014). Does Too Much Finance Harm Economic Growth? Journal of Banking and Finance, Vol. 41, pp. 36-44.

Lean, H. H. and Tan, B. W. (2011). Linkages between Foreign Direct Investment, Domestic Investment and Economic Growth in Malaysia. Journal of Economic Cooperation and Development, Vol. 32, No. 4, pp. 75-96.

Lee, C. And Chang, C. (2009). FDI, Financial Development and Economic Growth: International Evidence. Journal of Applied Economics, Vol. 12, No. 2, pp. 249-271.

Lee, C. G. (2010). Outward Foreign Direct Investment and Economic Growth: Evidence from Japan, Global Economic Review, Vol. 39, No. 3, pp. 317-326.

Lee, C., Huang, W. and Yin, C. (2013). The Dynamic Interactions among the Stock, Bond and Insurance Markets. North American Journal of Economics and Finance, Vol. 26, pp. 28-52.

Levine, A., Lin, C. F. and Chu, C. S. (2002). Unit Root Tests in Panel Data: Asymptotic and Finite Sample Properties. Journal of Econometrics, Vo. 108, No. 1, pp. 1-24.

Levine, R. (1991). Stock Markets, Growth, and Tax Policy. Journal of Finance, Vol. 46, No. 4, pp. 1445-1465.

Levine, R. (1997), Financial Development and Economic Growth: Views and Agenda, Journal of Economic Literature, Vol. 35, No. 20, pp. 688-726.

Levine, R. (1999). Law, Finance and Economic Growth. Journal of Financial Intermediation, Vol. 8, Nos. 1-2, pp. 8-35.

Levine, R. (2003). More on Finance and Growth: More Finance, More Growth? Federal Reserve Bank of St. Louis Review, Vol. 85, No. 6, pp. 31-46.

Levine, R. (2005). Finance and Growth: Theory and Evidence. In P. Aghion and S. Durlauf (EDs.), Handbook of Economic Growth. Elsevier Science, Amsterdam.

Levine, R. and Zervos, S. (1996). Stock Market Development and Long-run Growth. World Bank Economic Review, Vol. 10, No. 2, pp. 323-339. 
Levine, R. and Zervos, S. (1998). Stock Markets, Banks and Economic Growth. American Economic Review, Vol. 88, No. 3, pp. 537-558.

Levine, R., Loayza, N. and Beck, T. (2000). Financial Intermediation and Growth: Causality Analysis and Causes. Journal of Monetary Economics, Vol. 46, No. 1, pp. 31-77.

Lewis-Beck, M. (1994). Factor Analysis and Related Techniques. Sage Publications, New Delhi.

Liang, Q. and Teng, J. (2006). Financial Development and Economic Growth: Evidence from China. China Economic Review, Vol. 17, No. 4, pp. 395-411.

Liddle, B. and Lung, S. (2013). The Long-run causal Relationship between Transport Energy Consumption and GDP: Evidence from Heterogeneous Panel Methods Robust to Cross-sectional Dependence. Economic Letters, Vol. 121, No. 3, pp. 524-527.

Liu, X. and Sinclair, P. (2008). Does the Linkage between Stock Market Performance and Economic Growth Vary across Greater China. Applied Economics Letters, Vol. 15, No. 7, pp. 505-508.

Lucas, R. (1988). On the Mechanics of Economic Development. Journal of Monetary Economics, Vol. 22, No. 1, pp. 3- 42.

Luintel, K. and Khan, M. (1999). A Quantitative Reassessment of the Finance-Growth Nexus: Evidence from a Multivariate VAR. Journal of Development Economics, Vol. 60, No. 2, pp. 381- 405.

Maddala, G. S. and Wu, S. (1999). A Comparative Study of Unit Root Tests with Panel Data and New Sample Test. Oxford Bulletin of Economics and Statistics, Vol. 61, S1, pp. 631-652.

Majid, M. S. A. and Mahrizal (2007). Does Financial Development Cause Economic Growth in the ASEAN-4 Countries? Savings and Development, Vol. 31, No. 4, pp. 369-398.

Masih, A. M. M. and Masih, R. (1999). Are Asian Stock Market Fluctuations Due Mainly to IntraRegional Contagion Effects? Evidence Based on Asian Emerging Stock Markets. Pacific Basin Finance Journal, Vol. 7, Nos. 3-4, pp. 251-282.

McKinnon, R. (1973). Money and Capital in Economic Development. Brookings Institution, Washington DC.

Menyah, K., Nazlioglu, S. and Wolde-Rufael, Y. (2014). Financial Development, Trade Openness and Economic Growth in African Countries: New Insights from a Panel Causality Approach. Economic Modelling, Vol. 37, No. 2, pp. 386-394.

Mercelin, I. and Mathur, I. (2014). Financial Development, Institutions and Banks. International Review of Financial Analysis, Vol. 31, pp. 25-33.

Moshirian, F. and Wu, Q. (2012). Banking Industry Volatility and Economic Growth. Research in International Business and Finance, Vol. 26, No. 3, pp. 428-442.

Mukhopadhyay, B., Pradhan, R. P. and Feridun, M. (2011). Finance-growth Nexus Revisited for Some Asian countries. Applied Economics Letters, Vol. 18, No. 16, pp. 1527- 1530.

Muradoglu, G., Taskin, F. and Bigan, I. (2000). Causality between Stock Returns and Macroeconomic Variables in Emerging Markets. Russian and East European Finance and Trade, Vol. 36, No. 6, pp. 33-53.

Murthy, K. V. B. and Kalsie, A. (2013). Measurement of International Currency Crises: a Panel Data Approach using Composite Indices. Vikalpa, Vol. 38, No. 4, pp. 13-36.

Naceur, S. B. and Ghazouani, S. (2007). Stock Markets, Banks, and Economic Growth: Empirical Evidence from the MENA Region. Research in International Business and Finance, Vol. 21, No. 2, pp. 297-315.

Newey, W. and West, K. (1987). A Simple Positive Semi-Definite, Heteroskedasticity and Autocorrelation Consistent Covariance Matrix. Econometrica, Vol. 50, No. 3, pp. 703-708. 
Nieuwerburgh, S. V., Buelens, F. and Cuyvers, L. (2006). Stock Market Development and Economic Growth in Belgium. Explorations in Economic History, Vol. 43, No. 1, pp. 13-38.

Nishat, M. and Saghir, A. (1991). The Stock Market and Pakistan Economy -1964-87. Savings and Development, Vol. 15, No. 2, pp. 131-146.

Nowbutsing, B. M (1999). Stock Market Development and Economic Growth: The Case of Mauritius. International Business and Economics Research Journal, Vol. 8, No. 2, pp. 77-88.

Odhiambo, N. M. (2008). Financial Development in Kenya: A Dynamic Test of the Finance-led Growth Hypotheses. Economic Issues, Vol. 13, No. 2, pp. 21-36.

Odhiambo, N. M. (2010). Finance-Investment-Growth Nexus in South Africa: An ARDL Bounds Testing Procedure. Economic Change Restructuring, Vol. 43, No.3, pp. 205-219.

OECD (1999). The Future of the Global Economy: Towards a Long Boom. OECD Publishing, Organization for Economic Co-operation and Development, Paris.

OECD (2008). Handbook on Constructing Composite Indicators: Methodology and User Guide. OECD Publishing, Organization for Economic Co-operation and Development, Paris.

Pagano, M. (1993). Financial Markets and Growth: An Overview. European Economic Review, Vol. 37, Nos. 2-3, pp. 613-622.

Panopoulou, E. (2009). Financial Variables and Euro Area Growth: A Non-parametric Causality Analysis. Economic Modelling, Vol. 26, No. 6, pp. 1414-1419.

Pedroni, P. (1999). Critical values for Cointegration Tests in Heterogeneous Panels with Multiple Regressors. Oxford Bulletin of Economics and Statistics, Vol. 61, No. 1, pp. 653-670.

Pedroni, P. (2000). Fully Modified OLS for Heterogeneous Cointegrated Panels. Advanced in Econometrics, Vol. 15, No. 1, pp. 93-130.

Pesaran, M. H. and Shin, Y. (1998). Generalized Impulse Response Analysis in Linear Multivariate Models. Economics Letters, Vol. 58, No. 1, pp. 17-29.

Pradhan, R. P. (2013). The Determinants of Long-run Finance Development: The ARDL Bound Testing Approach. Journal of Social and Management Sciences, Vol. 52, No. 1, pp. 43-63.

Pradhan, R. P., Arvin, M. B., Bele, S. and Taneja, S. (2013a). The Impact of Stock Market Development on Inflation and Economic Growth of 16 Asian Countries: A Panel VAR Approach. Applied Econometrics and International Development, Vol. 13, No. 1, pp. 203-220.

Pradhan, R. P., Arvin, M. B., Norman, N. R. and Hall, J. H. (2014a). The Dynamics of Banking Sector and Stock Market Maturity and the Performance of Asian Economies. Journal of Economic and Administrative Sciences, Vol. 30, No.1, pp. 16-44.

Pradhan, R. P., Arvin, M. B., Norman, N. R. and Nishigaki, Y. (2014b). Does Banking Sector Development Affect Economic Growth and Inflation? A Panel Cointegration and Causality Approach. Applied Financial Economics, Vol. 24, No.7, pp. 465-480.

Pradhan, R. P., Dasgupta, P. and Samadhan, B. (2013b). Finance Development and Economic Growth in BRICS: A Panel Data Analysis. Journal of Quantitative Economics, Vol. 11, Nos. 12, pp. 308-322.

Pradhan, R. P., Mukhopadhyay, B., Gunashekar, A., Bele, S. and Pandey, S. (2013c). Financial Development, Social Development, and Economic Growth: The Causal Nexus in Asia. Decision, Vol. 40, Nos. 1-2, pp. 69-83.

Rajan, R. and Zingales, L. (1998). Finance Dependence and Growth. American Economic Review, Vo. 88, No. 3, pp. 559-586.

Rashid, A. (2008). Macroeconomic Variables and Stock Market Performance: Testing for Dynamic Linkages with a Known Structural Break. Savings and Development, Vol. 32, No. 1, pp. 77-102. 
Reinhart, C. M. and Tokatlidis, I. (2003). Financial Liberalization: The African Experience. Journal of African Economies. Vol. 12, No. 2, pp. 53-88.

Rousseau, P. and Yilmazkuday, H. (2009). Inflation, Financial Development and Growth: A Trilateral Analysis. Economic System, Vol. 33, No.4, pp. 310-324.

Rousseau, P. L. (2009). Share Liquidity, Participation, and Growth of the Boston Market for Industrial Equities, 1854-1897. Explorations in Economic History, Vol. 46, No. 2, pp. 203-219.

Rousseau, P. L. and Wachtel, P. (2000). Banks, Stock Markets and China's Great Leap Forward. Emerging Markets Review, Vol. 8, No. 3, pp. 206-217.

Rousseau, P. L. and Xiao, S. (2007). Equity Markets and Growth: Cross Country Evidence on Timing and Outcomes, 1980-1995. Journal of Banking and Finance, Vol. 24, No. 12, pp. 19331957.

Runkle, D. E. (1987). Vector Autoregressions and Reality. Journal of Business and Economics Statistics, Vol. 5, No. 4, pp. 437-442.

Schumpeter, J. A. (1911). The Theory of Economic Development. Harvard University Press, Cambridge, MA.

Shahbaz, M., Ahmed, N. and Ali, L. (2008). Stock Market Development and Economic Growth: ARDL Causality in Pakistan. International Research Journal of Finance and Economics, Vol. 14, pp. 1450-2887.

Shan, J., Morris, A. and Sun, F. (2001). Financial Development and Economic Growth: An EggChicken Problem? Review of International Economics, Vol. 9, No. 3, pp. 443-454.

Shaw, E. S. (1973). Financial Deepening in Economic Development. Oxford University Press, New York.

Shih, V., Zhng, Q. and Liu, M. (2007). Comparing the Performance of Chinese Banks: A Principal Component Approach. China Economic Review, Vol. 18, No. 1, pp. 15-34.

Singh, A. (1997). Financial Liberalization, Stock markets and Economic Development. Economic Journal, Vol. 107, No. 442, pp. 771-782.

Stern, N. H. (1989). The Economics of Development: A Survey. Economic Journal, Vol. 99, No. 397, pp. 597- 685.

Tang, T. C. (2005). An Examination of the Causal Relationship between Bank Lending and Economic Growth: Evidence from ASEAN. Savings and Development, Vol. 29, No. 3, pp. 313343.

Tang, T. C. and Wang, K. N. (2011). Foreign Direct Investment, Merchandise and Services Trade in a Transition Economy: The Case of Cambodia. International Economic Journal, Vol. 25, No. 2, pp. 251-267.

Thakor, A. V. (1996). The Design of Financial Systems: An Overview. Journal of Banking and Finance, Vol. 20, No. 5, pp. 917-948.

Thornton, J. (1994). Financial Deepening and Economic Growth: Evidence from Asian Economies. Savings and Development, Vol. 18, No. 1, pp. 41-51.

Trew, A. (2006). Finance and Growth: A Critical Survey. Economic Record, Vol. 82, No. 259, pp. 481-490.

Tsouma, E. (2009). Stock Returns and Economic Activity in Nature and Emerging Markets. Quarterly Review of Economics and Finance, Vol. 49, No. 2, pp. 668-685.

Uddin, G. S., Shahbaz, M., Arouri, M. and Teulon, F. (2014). Financial Development and Poverty Reduction Nexus: A cointegration and causality Analysis in Bangladesh. Economic Modelling, Vol. 36, No.1, pp. 405-412. 
Wachtel, P. (2003). How Much Do We Really Know about Growth and Finance? Federal Reserve Bank of Atlanta Economic Review, Vol. 88, No. 1, pp. 33-47.

Wold, S. (1978). Cross Validatory Estimation of the Number of Components in Factor and Principal Component Analysis. Technometrics, Vol. 20, No. 4, pp. 397-406.

Wolde-Rufael, Y. (2009). Re-examining the Financial Development and Economic Growth Nexus in Kenya. Economic Modelling, Vol. 26, No. 6, pp. 1140-1146.

Wongbangpo, P. and Sharma, S. C. (2002). Stock Market and Macroeconomic Fundamental Dynamic Interactions: ASEAN-5 Countries. Journal of Asian Economics, Vol. 13, No. 1, pp. 2751.

Wu, J., Hou, H. and Cheng, S. (2010). The Dynamic Impacts of Financial Institutions on Economic Growth: Evidence from the European Union. Journal of Macroeconomics, Vol. 32, No. 3, pp. 879-891.

Yartey, C. A. (2008). The Determinants of Stock Market Development in Emerging Economies: Is South Africa Different. IMF Working Paper, No. WP/ 08/ 32, pp. 1-31. International Monetary Fund, Washington DC.

Yilmazkuday, H. (2011). Thresholds in the Finance-growth Nexus: A Cross-country Analysis. World Bank Economic Review, Vol. 25, No. 2, pp. 278-295.

Yucel, F. (2009). Causal Relationships between Financial Development, Trade Openness, and Economic Growth: The Case of Turkey. Journal of Social Sciences, Vol. 5, No. 1, pp. 33-42.

Zaman, K. Izhar, Z., Khan, M. M. and Ahmad, M. (2012). The Relationship between Financial Indicators and Human Development in Pakistan. Economic Modelling, Vol. 29, No. 5, pp. 15151523.

Zhang, J., Wang, L. and Wang, S. (2012). Financial Development and Economic Growth: Recent Evidence from China. Journal of Comparative Economics, Vol. 40, No. 3, pp. 393-412.

Zhang, K. H. (2001). Does Foreign Direct Investment Promote Economic Growth? Evidence from East Asia and Latin America. Contemporary Economic Policy, Vol. 19, No. 2, pp. 175-185.

Zhu, A., Ash, M. and Pollin, R. (2004). Stock market liquidity and economic growth: A critical appraisal of the Levine/ Zervos model. International Review of Applied Economics, Vol. 18, No. 1, pp. 63-71.

Zivengwa, T., Mashika, J., Bokosi, F. K. and Makova, T. (2011). Stock Market Development and Economic Growth in Zimbabwe. International Journal of Economics and Finance, Vol. 3, No. 5, pp. 140-150.

Agbetsiafa D K (2003) 'The Finance Growth Nexus: Evidence from subSaharan Africa', Savings and Development, 28(3), 271-288.

Goldsmith, R. W. (1969). Financial Structure and Development, CT: Yale University Press, New Haven.

Rousseau, P. L. and Wachtel, P. (1998). Financial Intermediation and Economic Performance: Historical Evidence from Five Industrialized Countries. Journal of Money, Credit and Banking, Vol. 34, No. 4, pp. 657-678.

Pedroni, P. (2004). Panel Cointegration: Asymptotic and Finite Sample Properties of Pooled Time Series Tests with an Application to the PPP Hypothesis: New Results. Econometric Theory, Vol. 20, No. 3, pp. 597-627. 
Çoban, S. and Topcu, M. 2013. The nexus between financial development and energy consumption in the EU: A dynamic panel data analysis, Energy Economics, Vol. 39, No. 3, pp. 81-88.

Saci, K. and K. Holden (2008). Evidence on growth and financial development using principal components. Applied Financial Economics, 18 (19): 1549 $-1560$.

Manly, B. (1994). Multivariate Statistical Methods: A premier. Chapman \& Hall, London.

Sharma, S. (1996). Applied Multivariate Techniques. Wiley Publication, New York.

Joliffe, I. T. (2002). Principal Component Analysis, Second Edition. Springer, New York.

Creane, S., Goyal, R., Mobarak, A. M. and Sab, R. (2004). Financial Sector Development in the Middle East and North Africa. IMF Working Paper, No. WP/04/201. International Monetary Fund, Washington DC. 
Table 1. Summary of the Studies Showing a Causal Link between Banking Sector Development and Economic Growth

\begin{tabular}{|c|c|c|c|}
\hline Study & Study Area & Method & Period Covered \\
\hline \multicolumn{4}{|c|}{ Group 1: Studies that Support Supply-leading Hypothesis } \\
\hline Menyah et al. (2014) & 21 African countries & TVGC & $1965-2008$ \\
\hline Hsueh et al. (2013) & Ten Asian countries & BVGC & $1980-2007$ \\
\hline Bojanic (2012) & Bolivia & MVGC & $1940-2010$ \\
\hline Chaiechi (2012) & South Korea, Hong Kong, UK & MVGC & $1990-2006$ \\
\hline Kar et al. (2011) & 15 MENA countries & MVGC & $1980-2007$ \\
\hline Wu et al. (2010) & European Union & MVGC & $1976-2005$ \\
\hline Jalil et al. (2010) & China & TVGC & $1977-2006$ \\
\hline Abu-Bader and Abu-Qarn (2008b) & Egypt & TVGC & $1960-2001$ \\
\hline Ang (2008b) & Malaysia & MVGC & $1960-2003$ \\
\hline Naceur and Ghazouani (2007) & MENA region & MVGC & $1979-2003$ \\
\hline Boulila and Trabelsi (2004) & Tunisia & BVGC & $1962-1987$ \\
\hline Agbetsiafa (2003) & Sub-Saharan Africa & TVGC & $1963-2001$ \\
\hline Calderon and Liu (2003) & 109 countries & MVGC & 1960-1994 \\
\hline Thornton (1994) & Asian countries & BVGC & $1951-1990$ \\
\hline \multicolumn{4}{|c|}{ Group 2: Studies that Support Demand-Following Hypothesis } \\
\hline Pradhan et al. (2013c) & 15 Asian countries & MVGC & $1961-2011$ \\
\hline Kar et al. (2011) & 15 MENA countries & MVGC & $1980-2007$ \\
\hline Odhiambo (2010) & South Africa & MVGC & $1969-2006$ \\
\hline Panopoulou (2009) & 5 countries & MVGC & $1995-2007$ \\
\hline Colombage (2009) & 5 countries & MVGC & $1995-2007$ \\
\hline Odhiambo (2008) & Kenya & TVGC & $1969-2005$ \\
\hline Ang and McKibbin (2007) & Malaysia & MVGC & $1960-2001$ \\
\hline Liang and Teng (2006) & China & MVGC & $1952-2001$ \\
\hline \multicolumn{4}{|c|}{ Group 3: Studies that Support Feedback Hypothesis } \\
\hline Pradhan et al. (2014a) & Asian countries & MVGC & $1960-2011$ \\
\hline Pradhan et al. (2013b) & 5 BRICS countries & BVGC & 1989-2011 \\
\hline Chow and Fung (2011) & 69 countries & TVGC & $1970-2004$ \\
\hline Wold-Rufael (2009) & Kenya & QVGC & $1966-2005$ \\
\hline Dritsakis and Adamopoulos (2004) & Greece & TVGC & $1960-2000$ \\
\hline Craigwell et al. (2001) & Barbados & MVGC & 1974-1998 \\
\hline Ahmed and Ansari (1998) & India, Pakistan, Sri Lanka & MVGC & 1973-1991 \\
\hline
\end{tabular}

Note 1: The definition of banking sector development varies across studies.

Note 2: MMs: mature markets; EMs: Emerging markets; BVGC: Bivariate Granger Causality; TVGC: Trivariate Granger Causality; QVGC: Quadvariate Granger Causality; and MVGC: Multivariate Granger Causality. 
Table 2. Summary of the Studies Showing a Causal Link between Stock Market Development and Economic Growth

\begin{tabular}{|c|c|c|c|}
\hline Study & Study Area & Method & Period Covered \\
\hline \multicolumn{4}{|c|}{ Group 1: Studies that Support Supply-leading Hypothesis } \\
\hline Pradhan et al. (2013a) & 16 Asian countries & MVGC & $1988-2012$ \\
\hline Kolapo and Adaramola (2012) & Nigeria & MVGC & $1990-2010$ \\
\hline Tsouma (2009) & 22 MMs and EMs & BVGC & $1991-2006$ \\
\hline Enisan and Olufisayo (2009) & 7 Sub-Saharan African & MVGC & $1980-2004$ \\
\hline Colombage (2009) & 5 countries & MVGC & $1995-2007$ \\
\hline Nieuwerburgh et al. (2006) & Belgium & TVGC & $1830-2000$ \\
\hline \multicolumn{4}{|c|}{ Group 2: Studies that Support Demand-Following Hypothesis } \\
\hline Kar et al. (2011) & 15 MENA countries & MVGC & $1980-2007$ \\
\hline Panopoulou (2009) & 5 countries & MVGC & $1995-2007$ \\
\hline Odhiambo (2008) & Kenya & TVGC & $1969-2005$ \\
\hline Liu and Sinclair (2008) & China & BVGC & $1973-2003$ \\
\hline Ang et al. (2007) & Malaysia & MVGC & $1960-2001$ \\
\hline Liang and Teng (2006) & China & MVGC & $1952-2001$ \\
\hline Dritsaki and Dritsaki-Bargiota (2005) & Greece & TVGC & $1988-2002$ \\
\hline \multicolumn{4}{|c|}{ Group 3: Studies that Support Feedback Hypothesis } \\
\hline Cheng (2012) & Taiwan & MVGC & 1973-2007 \\
\hline Zhu et al. (2011) & 14 countries & MVGC & 1995-2009 \\
\hline Hou and Cheng (2010) & Taiwan & MVGC & 1971-2007 \\
\hline Rashid (2008) & Pakistan & MVGC & $1994-2205$ \\
\hline Darrat et al. (2006) & EMs & TVGC & $1970-2003$ \\
\hline Caporale et al. (2004) & 7 countries & BVGC & 1977-1998 \\
\hline Wongbangpo and Sharma (2002) & ASEAN 5 & MVGC & $1985-1996$ \\
\hline Huang et al. (2000) & US, Japan, China & TVGC & 1992-1997 \\
\hline Muradoglu et al. (2000) & EMs & MVGC & 1976-1997 \\
\hline Masih and Masih (1999) & 8 countries & MVGC & 1992-1997 \\
\hline Nishat and Saghir (1991) & Pakistan & BVGC & 1964-1987 \\
\hline
\end{tabular}

Note 1: The definition of stock market development varies across studies.

Note 2: MMs: mature markets; EMs: Emerging markets; BVGC: Bivariate Granger Causality; TVGC: Trivariate Granger Causality; QVGC: Quadvariate Granger Causality; and MVGC: Multivariate Granger Causality. 
Table 3. Definition of Variables used in Defining Banking Sector Development

Variable

Definition

BSD

Composite index of banking sector development: This utilizes four banking sector indicators: BRM, CPS, DCB, and DCP.

BRM

Broad money supply: Broad money supply, expressed as a percentage of gross domestic product, is the sum of currency outside banks; demand and term deposits, including foreign currency deposits of resident sectors (other than the central bank); certificates of deposit and commercial paper.

CPS

Claims on private sectors: Credit (expressed as a percentage of gross domestic product) refers to gross credit from the financial system to the private sector. It isolates credit issues to the private sector, as opposed to credit issued to government, government agencies, and public enterprises.

DCB

Domestic credit provided by the banking sector: It includes all credit to various sectors on a gross basis, with the exception of credit to the central government. It is expressed as a percentage of gross domestic product.

DCP Domestic credit to the private sector: This credit, expressed as a percentage of gross domestic product, refers to financial resources provided to the private sector, such as through loans, purchases of non-equity securities, trade credits and other accounts receivable that establish a claim for payment.

Note 1: All monetary measures are in real US dollars.

Note 2: All variables above are defined in the World Development Indicators and published by the World Bank.

Note 3: We use the natural log of these variables in our estimation. 
Table 4. Definition of Variables used in Defining Stock Market Development

Variable

Definition

SMD

Composite index of stock market development: This utilizes four stock market indicators: MAC, TRA, TUR, and NLC.

MAC

Market capitalization: Percentage change in the market capitalization of the listed companies.

TRA

Traded stocks: Percentage change in the total value of traded stocks.

TUR

Turnover ratio: Percentage change in the turnover ratio in the stock market.

NLC

Number of listed companies: It is an additional measure of stock market size and is measured as a percentage of gross domestic product.

Note 1: All monetary measures are in real US dollars.

Note 2: All variables above are defined in the World Development Indicators and published by the World Bank.

Note 3: We use the natural log of these variables in our estimation. 
Table 5. Definition of Economic Growth and our other Four Macroeconomic Variables

Variable

Definition

GDP

Per capita economic growth rate: The percentage change in per capita gross domestic product, used as our indicator of economic growth.

FDI

Foreign Direct Investment (FDI) inflows: This is expressed as a percentage of gross domestic product.

OPE

Trade openness: Measured as total trade (exports plus imports) as a percentage of gross domestic product, used to gauge how open the economy is.

INF Inflation rate: Measured in percentage change by using the Consumer Price Index.

GCE Government final consumption expenditure: Measured as a percentage of gross domestic product to capture the degree of government involvement in the economy.

Note 1: All monetary measures are in real US dollars.

Note 2: All variables above are defined in the World Development Indicators and published by the World Bank.

Note 3: We use the natural log of these variables in our estimation.

Note 4: The set of macroeconomic variables above (other than GDP) is denoted by MED in the text and in Figures 1 and 2. 
Table 6. Summary Statistics on the Variables

\begin{tabular}{|c|c|c|c|c|c|c|c|c|c|}
\hline Variable & Mean & Med & Max & Min & Std & Skew & Kur & $\mathbf{J B}$ & Pr \\
\hline \multicolumn{10}{|c|}{ Panel 1: Member Countries (AMC) } \\
\hline BSD & 0.28 & 0.32 & 0.57 & -0.22 & 0.20 & -0.48 & 1.99 & 9.90 & 0.01 \\
\hline SMD & 0.04 & 0.06 & 0.58 & -0.71 & 0.27 & -0.34 & 2.60 & 3.16 & 0.21 \\
\hline GDP & 1.25 & 1.28 & 1.44 & -0.15 & 0.17 & -5.34 & 40.0 & 76.0 & 0.00 \\
\hline FDI & 0.95 & 0.90 & 1.52 & 0.35 & 0.21 & 0.68 & 3.76 & 12.3 & 0.00 \\
\hline OPE & 2.11 & 2.10 & 2.66 & 1.66 & 0.29 & 0.27 & 2.00 & 6.69 & 0.04 \\
\hline INF & 0.80 & 0.82 & 1.78 & 0.06 & 0.26 & 0.21 & 4.39 & 10.8 & 0.00 \\
\hline GCE & 0.99 & 0.99 & 1.15 & 0.76 & 0.09 & -0.67 & 2.98 & 9.18 & 0.01 \\
\hline \multicolumn{10}{|c|}{ Panel 2: Dialogue Partners Countries (ADC) } \\
\hline BSD & 0.16 & 0.19 & 0.63 & -0.80 & 0.29 & -0.72 & 3.39 & 18.1 & 0.00 \\
\hline SMD & 0.01 & 0.01 & 0.62 & -1.23 & 0.30 & -0.70 & 4.11 & 25.6 & 0.00 \\
\hline GDP & 1.25 & 1.25 & 1.46 & 0.86 & 0.10 & -0.85 & 5.40 & 69.7 & 0.00 \\
\hline FDI & 0.83 & 0.81 & 1.15 & 0.17 & 0.11 & -0.48 & 7.56 & 17.5 & 0.00 \\
\hline OPE & 1.62 & 1.65 & 2.04 & 1.17 & 0.21 & -0.33 & 2.06 & 10.5 & 0.00 \\
\hline INF & 0.73 & 0.69 & 2.30 & -0.23 & 0.33 & 0.72 & 6.43 & 11.2 & 0.00 \\
\hline GCE & 1.20 & 1.23 & 1.38 & 1.01 & 0.08 & -0.39 & 2.34 & 8.46 & 0.01 \\
\hline \multicolumn{10}{|c|}{ Panel 3: Observer Countries (AOC) } \\
\hline BSD & 0.40 & 0.44 & 0.68 & -0.23 & 0.16 & -1.28 & 5.28 & 46.3 & 0.00 \\
\hline SMD & -0.26 & -0.33 & 0.61 & -0.87 & 0.33 & 0.82 & 3.44 & 11.3 & 0.00 \\
\hline GDP & 1.26 & 1.26 & 1.49 & 1.08 & 0.06 & 0.02 & 4.49 & 8.82 & 0.01 \\
\hline FDI & 0.83 & 0.78 & 1.77 & 0.42 & 0.18 & 2.70 & 13.0 & 51.0 & 0.00 \\
\hline OPE & 1.75 & 1.74 & 2.17 & 1.28 & 0.25 & 0.03 & 1.75 & 6.21 & 0.05 \\
\hline INF & 0.99 & 1.00 & 1.69 & 0.46 & 0.22 & 0.14 & 3.97 & 4.06 & 0.13 \\
\hline GCE & 0.98 & 1.02 & 1.25 & 0.62 & 0.19 & -0.61 & 2.07 & 9.31 & 0.01 \\
\hline \multicolumn{10}{|c|}{ Panel 4: Total ARF Countries (ATC) } \\
\hline BSD & 0.08 & 0.11 & 0.64 & -0.84 & 0.28 & -0.16 & 2.41 & 7.80 & 0.02 \\
\hline SMD & -0.23 & -0.17 & 0.66 & -1.60 & 0.43 & -0.56 & 2.90 & 21.7 & 0.00 \\
\hline GDP & 1.25 & 1.25 & 1.49 & -0.15 & 0.12 & -5.01 & 4.79 & 36.3 & 0.00 \\
\hline FDI & 0.86 & 0.82 & 1.77 & 0.17 & 0.17 & 1.37 & 7.52 & 47.9 & 0.00 \\
\hline OPE & 1.80 & 1.77 & 2.66 & 1.17 & 0.32 & 0.52 & 3.00 & 18.3 & 0.00 \\
\hline INF & 0.81 & 0.80 & 2.49 & -0.23 & 0.31 & 0.57 & 6.14 & 22.5 & 0.00 \\
\hline GCE & 1.09 & 1.10 & 1.38 & 0.62 & 0.16 & -0.82 & 3.45 & 49.5 & 0.00 \\
\hline
\end{tabular}

Note 1: Med: Median; Max: Maximum; Min: Minimum; Std: Standard Deviation; Skew: Skewness; Kur: Kurtosis; JB: Jarque Bera Statistics; Pr: Probability.

Note 2: GDP is per capita economic growth rate; BSD is banking sector development index; SMD is stock market development index, FDI is foreign direct investment inflows; OPE is trade openness; INF is inflation rate; GCE is government consumption expenditure. Variables are defined more precisely under Tables 3-5.

Note 3: Values reported here are the natural logs of the variables. We use natural log forms in our estimation.

Note 4: $A M C$ involves ten countries, namely Brunei, Burma, Cambodia, Indonesia, Laos, Malaysia, Philippines, Singapore, Thailand, and Vietnam; $A D C$ involves nine countries, namely Australia, Canada, China, India, Japan, New Zealand, the Korean Republic, the Russian Federation and the United States; $A O C$ involves six countries, namely Papua New Guinea, Mongolia, Pakistan, East Timor, Bangladesh, Sri Lanka; and ATC involves a total 25 ARF countries. 
Table 7. The Correlation Matrix

\begin{tabular}{|c|c|c|c|c|c|c|c|}
\hline Variable & BSD & SMD & GDP & FDI & OPE & INF & GCE \\
\hline \multicolumn{8}{|c|}{ Panel 1: Member Countries (AMC) } \\
\hline $\begin{array}{l}\text { BSD } \\
\text { SMD } \\
\text { GDP } \\
\text { FDI } \\
\text { OPE } \\
\text { INF } \\
\text { GCE }\end{array}$ & 1.00 & $\begin{array}{l}0.67^{*} \\
\mathbf{1 . 0 0}\end{array}$ & $\begin{array}{l}-0.05 \\
0.06 \\
\mathbf{1 . 0 0}\end{array}$ & $\begin{array}{l}0.46^{*} \\
0.55^{*} \\
0.15 \\
\mathbf{1 . 0 0}\end{array}$ & $\begin{array}{l}0.63^{*} \\
0.64^{*} \\
0.01 \\
0.81^{*} \\
\mathbf{1 . 0 0}\end{array}$ & $\begin{array}{l}-0.49^{* *} \\
-0.60^{*} \\
-0.25 \\
-0.42^{* *} \\
-0.58^{*} \\
\mathbf{1 . 0 0}\end{array}$ & $\begin{array}{l}0.37 \\
0.50 * \\
0.06 \\
0.16 \\
0.27 \\
-0.58^{*} \\
\mathbf{1 . 0 0}\end{array}$ \\
\hline \multicolumn{8}{|c|}{ Panel 2: Dialogue Partners Countries (ADC) } \\
\hline $\begin{array}{l}\text { BSD } \\
\text { SMD } \\
\text { GDP } \\
\text { FDI } \\
\text { OPE } \\
\text { INF } \\
\text { GCE }\end{array}$ & 1.00 & $\begin{array}{l}0.50^{* *} \\
\mathbf{1 . 0 0}\end{array}$ & $\begin{array}{l}-0.15 \\
0.13 \\
\mathbf{1 . 0 0}\end{array}$ & $\begin{array}{l}0.01 \\
-0.06 \\
0.19 \\
\mathbf{1 . 0 0}\end{array}$ & $\begin{array}{l}-0.24 \\
-0.19 \\
0.15 \\
0.35 \\
\mathbf{1 . 0 0}\end{array}$ & $\begin{array}{l}-0.77^{*} \\
-0.40^{* *} \\
0.09 \\
0.06 \\
0.17 \\
\mathbf{1 . 0 0}\end{array}$ & $\begin{array}{l}0.25 \\
-0.25 \\
-0.49^{* *} \\
0.17 \\
0.21 \\
-0.23 \\
\mathbf{1 . 0 0}\end{array}$ \\
\hline \multicolumn{8}{|c|}{ Panel 3: Observer Countries (AOC) } \\
\hline $\begin{array}{l}\text { BSD } \\
\text { SMD } \\
\text { GDP } \\
\text { FDI } \\
\text { OPE } \\
\text { INF } \\
\text { GCE }\end{array}$ & 1.00 & $\begin{array}{l}0.35 \\
\mathbf{1 . 0 0}\end{array}$ & $\begin{array}{l}0.36 \\
-0.01 \\
\mathbf{1 . 0 0}\end{array}$ & $\begin{array}{l}0.16 \\
0.06 \\
0.33 \\
\mathbf{1 . 0 0}\end{array}$ & $\begin{array}{l}-0.12 \\
-0.28 \\
0.23 \\
0.47 \\
\mathbf{1 . 0 0}\end{array}$ & $\begin{array}{l}-0.10 \\
0.01 \\
0.04 \\
0.15 \\
0.14 \\
\mathbf{1 . 0 0}\end{array}$ & $\begin{array}{l}-0.09 \\
0.09 \\
-0.02 \\
0.40^{* *} \\
0.66^{*} \\
0.28 \\
\mathbf{1 . 0 0}\end{array}$ \\
\hline \multicolumn{8}{|c|}{ Panel 4: Total ARF Countries (ATC) } \\
\hline $\begin{array}{l}\text { BSD } \\
\text { SMD } \\
\text { GDP } \\
\text { FDI } \\
\text { OPE } \\
\text { INF } \\
\text { GCE }\end{array}$ & 1.00 & $\begin{array}{l}0.66^{*} \\
\mathbf{1 . 0 0}\end{array}$ & $\begin{array}{l}-0.03 \\
0.03 \\
\mathbf{1 . 0 0}\end{array}$ & $\begin{array}{l}0.18 \\
0.12 \\
0.17 \\
\mathbf{1 . 0 0}\end{array}$ & $\begin{array}{l}0.02 \\
-0.03 \\
0.07 \\
0.63^{*} \\
\mathbf{1 . 0 0}\end{array}$ & $\begin{array}{l}-0.64^{*} \\
-0.46^{* *} \\
-0.12 \\
-0.10 \\
-0.01 \\
\mathbf{1 . 0 0}\end{array}$ & $\begin{array}{l}0.39 * * \\
0.36^{* *} \\
-0.11 \\
0.04 \\
-0.12 \\
-0.25 \\
\mathbf{1 . 0 0}\end{array}$ \\
\hline
\end{tabular}

Note 1: GDP is per capita economic growth rate; BSD is banking sector development index; SMD is stock market development index, FDI is foreign direct investment inflows; OPE is trade openness; INF is inflation rate; GCE is government consumption expenditure. Variables are defined more precisely under Tables 3-5.

Note 2: * indicates significance at the 5\% level; ** indicates significance at the $10 \%$ level. 
Table 8. Results from Panel Unit Root Test

\begin{tabular}{|c|c|c|c|c|c|c|c|}
\hline Variable & BSD & SMD & GDP & FDI & OPE & INF & GCE \\
\hline \multicolumn{8}{|c|}{ Panel 1: Member Countries (AMC) } \\
\hline \multicolumn{8}{|c|}{ Case 1: Level data } \\
\hline LLC & 1.07 & -1.83 & -0.96 & -0.38 & 1.42 & -1.20 & 1.45 \\
\hline ADF & 11.1 & 21.7 & 8.04 & 5.70 & 2.87 & 8.80 & 4.09 \\
\hline $\mathbf{P P}$ & 12.7 & 24.1 & 10.4 & 4.59 & 1.96 & 8.36 & 4.17 \\
\hline \multicolumn{8}{|c|}{ Case 2: First Differenced Data } \\
\hline LLC & $-8.56 *$ & $-8.51 *$ & $-12.9 *$ & $-9.01 *$ & $-7.68 *$ & $-13.5^{*}$ & $-6.27 *$ \\
\hline ADF & $77.3^{*}$ & $75.5^{*}$ & $122 *$ & $85.2 *$ & $71.1^{*}$ & $126^{*}$ & $50.2 * *$ \\
\hline $\mathbf{P P}$ & $121 *$ & $134 *$ & $132 *$ & $138^{*}$ & $104 *$ & $172 *$ & $92.5^{*}$ \\
\hline \multicolumn{8}{|c|}{ Panel 2: Dialogue Partners Countries (ADC) } \\
\hline \multicolumn{8}{|c|}{ Case 1: Level data } \\
\hline LLC & 1.75 & -2.34 & -0.63 & -0.05 & 2.72 & -1.68 & 0.98 \\
\hline ADF & 12.0 & 36.9 & 9.22 & 9.27 & 2.91 & 27.1 & 8.24 \\
\hline PP & 14.9 & 31.1 & 12.4 & 7.20 & 2.11 & 27.9 & 8.10 \\
\hline \multicolumn{8}{|c|}{ Case 2: First Differenced Data } \\
\hline LLC & $-5.58 *$ & $-9.59 *$ & $-14.0 *$ & -11.1 & $-7.26^{*}$ & $-12.4^{*}$ & $-8.48^{*}$ \\
\hline ADF & $60.8^{* *}$ & $110^{*}$ & $171 *$ & 133.2 & $82.3^{*}$ & $147 *$ & $93.9 *$ \\
\hline $\mathbf{P P}$ & $107 *$ & $179^{*}$ & $232 *$ & 173.6 & $144^{*}$ & $219^{*}$ & $102 *$ \\
\hline \multicolumn{8}{|c|}{ Panel 3: Observer Countries (AOC) } \\
\hline \multicolumn{8}{|c|}{ Case 1: Level data } \\
\hline LLC & 0.87 & -1.39 & 1.93 & 0.80 & 0.52 & -0.87 & -0.24 \\
\hline ADF & 2.83 & 14.9 & 1.94 & 4.61 & 5.00 & 8.87 & 13.3 \\
\hline $\mathbf{P P}$ & 2.84 & 19.3 & 1.14 & 3.54 & 3.69 & 8.12 & 22.6 \\
\hline \multicolumn{8}{|c|}{ Case 2: First Differenced Data } \\
\hline LLC & $-6.14 *$ & $-5.91 *$ & $-9.30 *$ & $-6.20 *$ & $-5.33 *$ & $-9.77 *$ & $-5.99 *$ \\
\hline ADF & $48.7 *$ & $44.1 *$ & $79.1 *$ & $51.9 * *$ & $41.1 * *$ & $81.5^{*}$ & $45.5^{* *}$ \\
\hline $\mathbf{P P}$ & $78.9 *$ & $74.6^{*}$ & $105^{*}$ & $82.3^{*}$ & $64.5^{* *}$ & $115^{*}$ & $77.8^{*}$ \\
\hline \multicolumn{8}{|c|}{ Panel 4: Total ARF Countries (ATC) } \\
\hline \multicolumn{8}{|c|}{ Case 1: Level data } \\
\hline LLC & 1.54 & 0.29 & 0.81 & 0.31 & 2.91 & -1.88 & 1.37 \\
\hline ADF & 46.2 & 40.0 & 19.2 & 19.6 & 10.8 & 44.7 & 25.6 \\
\hline PP & 35.2 & 41.9 & 23.9 & 15.3 & 7.76 & 44.4 & 34.9 \\
\hline \multicolumn{8}{|c|}{ Case 2: First Differenced Data } \\
\hline LLC & $-12.2^{*}$ & $-7.64 *$ & $-21.0^{*}$ & $-15.5^{*}$ & $-11.6^{*}$ & $-20.1^{*}$ & $-11.9^{*}$ \\
\hline ADF & $202 *$ & $127 *$ & $372 *$ & $270 *$ & $194 *$ & $354 *$ & $190 *$ \\
\hline $\mathbf{P P}$ & $327 *$ & $300 *$ & $469^{*}$ & $393 *$ & $312 *$ & $506 *$ & $273 *$ \\
\hline
\end{tabular}

Note 1: GDP is per capita economic growth rate; BSD is banking sector development index; SMD is stock market development index, FDI is foreign direct investment inflows; OPE is trade openness; INF is inflation rate; GCE is gross consumption expenditure. Variables are defined more precisely under Tables 3-5.

Note 2: LLC: Levine-Lin-Chu statistics; ADF: Augmented Dickey Fuller statistics; PP: Phillips Perron statistics.

Note 3: The null hypothesis is that the variable follows a unit root process.

Note 4: $* *$ indicates significance at the $1 \%$ level; and * indicates significance at the $5 \%$ level.

Note 5: Methods used: Levine et al. (2002); Maddala and Wu (1999). 
Table 9. Results of Pedroni Panel Cointegration Test

\begin{tabular}{|c|c|c|c|c|c|c|}
\hline $\begin{array}{l}\text { Test } \\
\text { statistics }\end{array}$ & \multicolumn{2}{|c|}{$\begin{array}{l}\text { No Intercept } \\
\text { \& No Trend }\end{array}$} & \multicolumn{2}{|c|}{$\begin{array}{l}\text { Deterministic } \\
\text { Intercept Only }\end{array}$} & \multicolumn{2}{|c|}{$\begin{array}{l}\text { Deterministic } \\
\text { Intercept \& Trend }\end{array}$} \\
\hline \multicolumn{7}{|c|}{ Panel A: Member Countries (AMC) } \\
\hline Panel v- Statistics & -0.30 & {$[0.62]$} & -0.55 & {$[0.70]$} & -0.74 & [0.77] \\
\hline Panel $\rho$ - Statistics & -0.06 & {$[0.48]$} & -0.12 & {$[0.45]$} & 1.00 & [0.84] \\
\hline Panel PP-Statistics & $-4.42 *$ & {$[0.00]$} & $-4.98 *$ & {$[0.00]$} & $-3.68 *$ & {$[0.00]$} \\
\hline Panel ADF- Statistics & -1.40 & [0.08] & -1.11 & [0.13] & -0.52 & {$[0.30]$} \\
\hline Group $\rho$ - Statistics & -1.28 & [0.89] & 1.17 & {$[0.88]$} & 2.33 & [0.99] \\
\hline Group PP- Statistics & $-3.20 *$ & {$[0.00]$} & $-3.86^{*}$ & {$[0.00]$} & $-2.24 *$ & {$[0.01]$} \\
\hline $\begin{array}{l}\text { Group ADF- Statistics } \\
\text { Inference: Cointegrated }\end{array}$ & -0.58 & {$[0.20]$} & 0.18 & {$[0.42]$} & 0.38 & {$[0.64]$} \\
\hline \multicolumn{7}{|c|}{ Panel B: Dialogue Partners Countries (ADC) } \\
\hline Panel v- Statistics & -0.97 & [0.83] & -1.41 & {$[0.92]$} & 1.44 & [0.07] \\
\hline Panel $\rho$ - Statistics & 1.76 & [0.96] & 2.60 & [0.99] & 4.29 & {$[1.00]$} \\
\hline Panel PP- Statistics & $-3.30 *$ & {$[0.00]$} & $-1.87 *$ & [0.01] & $-2.80 *$ & {$[0.00]$} \\
\hline Panel ADF- Statistics & 2.52 & [0.99] & 3.42 & [0.99] & 0.97 & {$[0.83]$} \\
\hline Group $\rho$ - Statistics & 3.42 & [0.99] & 3.87 & [0.99] & 5.13 & {$[1.00]$} \\
\hline Group PP- Statistics & $-1.39 * *$ & [0.02] & -1.80 & {$[0.01]$} & -3.26 & {$[0.01]$} \\
\hline $\begin{array}{l}\text { Group ADF- Statistics } \\
\text { Inference: Cointegrated }\end{array}$ & 3.70 & {$[0.99]$} & 4.34 & {$[1.00]$} & 3.85 & {$[0.99]$} \\
\hline \multicolumn{7}{|c|}{ Panel C: Observer Countries (AOC) } \\
\hline Panel v- Statistics & -0.94 & {$[0.83]$} & -1.02 & {$[0.84]$} & 0.57 & {$[0.29]$} \\
\hline Panel $\rho$ - Statistics & 0.49 & [0.69] & 1.12 & [0.87] & 1.11 & [0.87] \\
\hline Panel PP-Statistics & $-1.89 * *$ & {$[0.03]$} & -1.17 & {$[0.12]$} & $-5.52 *$ & {$[0.00]$} \\
\hline Panel ADF- Statistics & 2.24 & {$[0.99]$} & 3.26 & [0.99] & 0.14 & {$[0.55]$} \\
\hline Group $\rho$ - Statistics & 1.61 & {$[0.25]$} & 2.43 & {$[0.99]$} & 2.47 & [0.99] \\
\hline Group PP- Statistics & $-2.83 *$ & {$[0.00]$} & $-2.34 *$ & {$[0.00]$} & $-6.71 *$ & {$[0.00]$} \\
\hline $\begin{array}{l}\text { Group ADF- Statistics } \\
\text { Inference: Cointegrated }\end{array}$ & 2.42 & {$[0.99]$} & 1.89 & {$[0.97]$} & -1.03 & {$[0.15]$} \\
\hline \multicolumn{7}{|c|}{ Panel D: Total ARF Countries (ATC) } \\
\hline Panel v- Statistics & -1.97 & [0.98] & -2.16 & [0.98] & -0.09 & [0.53] \\
\hline Panel $\rho$ - Statistics & 1.32 & {$[0.91]$} & 2.23 & [0.99] & 3.24 & [0.99] \\
\hline Panel PP- Statistics & $-3.16^{*}$ & {$[0.00]$} & $-2.23 *$ & [0.01] & $-6.55^{*}$ & {$[0.00]$} \\
\hline Panel ADF- Statistics & 2.80 & [0.99] & 3.99 & {$[1.00]$} & -0.12 & [0.45] \\
\hline Group $\rho$ - Statistics & 3.85 & [0.99] & 4.57 & {$[1.00]$} & 5.63 & {$[1.00]$} \\
\hline Group PP- Statistics & $-1.85 * *$ & {$[0.03]$} & $-1.28 *$ & {$[0.03]$} & $-4.24 *$ & {$[0.00]$} \\
\hline Group ADF- Statistics & 3.86 & [099] & 4.24 & {$[1.00]$} & 1.92 & {$[0.97]$} \\
\hline
\end{tabular}

Note 1: Variables and regions shown above are defined in the text. Natural log forms are used in our estimation.

Note 2: The null hypothesis is that the variables are not cointegrated.

Note 3: Figures in square brackets are probability levels indicating significance.

Note 4: * indicates significance at the $1 \%$ level; and $* *$ indicates significance at the $5 \%$ level.

Note 5: ADF: Augmented Dickey Fuller statistics; PP: Phillips Perron statistics; the other statistics are defined in Pedroni $(1999,2004)$. 
Table 10. Granger Causality Test Results

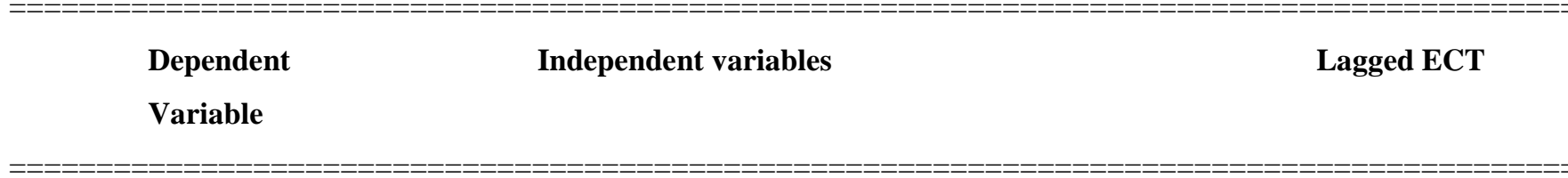

Panel 1: Member Countries (AMC)

$\begin{array}{lllllllll} & \Delta \text { BSD } & \Delta \text { SMD } & \Delta \text { GDP } & \Delta \text { FDI } & \Delta \text { OPE } & \Delta \text { INF } & \Delta \text { GCE } & \text { ECT-1 } \\ \Delta \text { BSD } & ----- & 0.93 & 1.09 & 2.53 & 11.0^{*} & 0.85 & 0.20 & -3.21^{*} \\ \Delta \text { SMD } & 8.98^{*} & ------ & 1.97 & 0.46 & 1.55 & 0.52 & 1.53 & -0.68 \\ \Delta \text { GDP } & 2.25 & 4.58^{*} & ----- & 3.87^{* *} & 0.79 & 0.87 & 4.10^{*} & -3.38^{*} \\ \Delta \text { FDI } & 2.43 & 2.61 & 3.34 * & ---- & 2.65 & 3.39^{* *} & 3.87^{* *} & -2.47^{* *} \\ \Delta \text { OPE } & 4.41^{*} & 1.10 & 6.57^{*} & 3.86^{* *} & ---- & 5.72^{*} & 4.92^{*} & -2.47^{* *} \\ \Delta \text { INF } & 0.66 & 0.97 & 1.55 & 1.37 & 0.55 & ----- & 4.02^{*} & -1.96 \\ \Delta \text { GCE } & 6.56^{*} & 3.49^{* *} & 11.6^{*} & 3.36^{* *} & 3.39 * * & 12.7^{*} & ----- & -2.92^{* *}\end{array}$

Panel 2: Dialogue Partners Countries (ADC)

$\begin{array}{lllllllll} & \Delta \text { BSD } & \Delta \text { SMD } & \Delta \text { GDP } & \Delta \text { FDI } & \Delta \text { OPE } & \Delta \text { INF } & \Delta \text { GCE } & \text { ECT.1 } \\ \Delta \text { BSD } & ----- & 1.26 & 0.92 & 3.60^{* *} & 2.41 & 1.70 & 13.3^{*} & 0.59 \\ \Delta \text { SMD } & 5.02 * & ----- & 5.72 * & 2.59 & 14.6^{*} & 7.12^{*} & 2.12 & 1.42 \\ \Delta \text { GDP } & 3.53^{* *} & 6.29 * & ----- & 4.38^{*} & 2.17 & 0.22 & 7.86^{*} & -3.93^{*} \\ \Delta \text { FDI } & 4.03 * & 2.77 & 0.86 & ----- & 5.82^{*} & 2.36 & 0.30 & 1.47 \\ \Delta \text { OPE } & 2.46 & 7.43^{*} & 3.34 * * & 1.51 & ----- & 4.64^{*} & 14.7^{*} & -2.86^{* *} \\ \Delta \text { INF } & 5.65^{*} & 3.20^{* *} & 18.2^{*} & 1.96 & 1.05 & ----- & 3.82^{* *} & -3.37^{*} \\ \Delta \text { GCE } & 6.09 * & 7.19 * & 2.78 & 0.56 & 6.05^{*} & 1.74 & ----- & 0.17\end{array}$

Panel 3: Observer Countries (AOC)

$\begin{array}{lllllllll} & \Delta \text { BSD } & \Delta \text { SMD } & \Delta \text { GDP } & \Delta \text { FDI } & \Delta \text { OPE } & \Delta \text { INF } & \Delta \text { GCE } & \text { ECT }_{-1} \\ \Delta \text { BSD } & ----- & 0.60 & 0.73 & 2.95 & 2.35 & 8.63 * & 0.51 & -0.01 \\ \Delta \text { SMD } & 4.75^{*} & ----- & 0.52 & 10.3 * & 8.99 * & 0.65 & 0.12 & 2.29 \\ \Delta \text { GDP } & 15.3^{*} & 5.39 * & ----- & 2.55 & 6.31^{*} & 2.22 & 8.65^{*} & -2.73 * * \\ \Delta \text { FDI } & 1.46 & 10.1 * & 2.74 & ----- & 10.7 * & 1.87 & 0.95 & -3.94 * \\ \Delta \text { OPE } & 0.84 & 0.64 & 3.72 * * & 1.06 & ----- & 4.22 * & 3.40^{* *} & -0.57\end{array}$




$\begin{array}{lllllllll}\Delta \mathbf{I N F} & 5.73 * & 1.27 & 2.59 & 1.84 & 0.77 & ----- & 4.25 * & 0.56 \\ \Delta \mathbf{G C E} & 3.65^{* *} & 5.89 * & 1.75 & 3.49 * * & 2.50 & 0.90 & ----- & 0.07\end{array}$

Panel 4: Total ARF Countries (ATC)

$\begin{array}{lllllllll} & \Delta \text { BSD } & \Delta \text { SMD } & \Delta \text { GDP } & \Delta \text { FDI } & \Delta \text { OPE } & \Delta \mathbf{I N F} & \Delta \text { GCE } & \text { ECT }_{-1} \\ \Delta \text { BSD } & ----- & 2.73 & 1.06 & 2.29 & 6.24^{*} & 4.54^{*} & 0.45 & -1.55 \\ \Delta \text { SMD } & 8.94^{*} & ----- & 2.01 & 0.02 & 1.66 & 0.42 & 0.82 & -0.24 \\ \Delta \text { GDP } & 0.79 & 10.7 * & ----- & 7.26^{*} & 3.48^{* *} & 1.48 & 1.45 & -7.51^{*} \\ \Delta \text { FDI } & 2.93 & 2.43 & 2.76 & ----- & 3.78^{* *} & 0.43 & 3.48^{* *} & -1.19 \\ \Delta \text { OPE } & 7.02^{*} & 4.59^{* *} & 12.4 * & 1.53 & ----- & 22.5^{*} & 14.9^{*} & -2.71^{* *} \\ \Delta \mathbf{I N F} & 13.2^{*} & 4.76^{* *} & 2.71 & 2.00 & 1.81 & ----- & 3.38^{* *} & -2.01 \\ \Delta \text { GCE } & 6.44^{*} & 6.13^{*} & 1.77 & 1.43 & 3.51^{* *} & 1.32 & ----- & -0.46\end{array}$

Note 1: GDP is per capita economic growth rate; BSD is banking sector development index; SMD is stock market development index, FDI is foreign direct investment inflows; OPE is trade openness; INF is inflation rate; $\mathrm{GCE}$ is government consumption expenditure; $\mathrm{ECT}_{-1}$ is lagged error-correction term.

Note 2: The study uses Akaike information criterion (AIC) and Schwarz information criterion (SIC) to determine the optimum lag length. Like the standard information criteria, a smaller SIC (or AIC) indicates a better fit of the model to data.

Note 3: * and ** indicate that the parameter estimates are significant at the $1 \%$ and $5 \%$ levels, respectively. 
Table 11. The Summary of Short-run Granger Causality

\begin{tabular}{|c|c|c|c|c|}
\hline $\begin{array}{c}\text { Causal } \\
\text { Relationships } \\
\text { Tested in the } \\
\text { Model }\end{array}$ & $\begin{array}{l}\text { Direction of } \\
\text { Relationships } \\
\text { Observed in } \\
\text { ARF Member } \\
\text { Countries }\end{array}$ & $\begin{array}{c}\text { Direction of } \\
\text { Relationships } \\
\text { Observed in } \\
\text { ARF Dialogue } \\
\text { Partners } \\
\text { Countries } \\
\end{array}$ & $\begin{array}{l}\text { Direction of } \\
\text { Relationships } \\
\text { Observed in } \\
\text { ARF Observer } \\
\text { Countries }\end{array}$ & $\begin{array}{c}\text { Direction of } \\
\text { Relationships } \\
\text { Observed in All } \\
\text { ARF Countries }\end{array}$ \\
\hline BSD vs. SMD & $\mathrm{BSD} \Rightarrow \mathrm{SMD}$ & $\mathrm{BSD}=>\mathrm{SMD}$ & $\mathrm{BSD}=>\mathrm{SMD}$ & $\mathrm{BSD}=>\mathrm{SMD}$ \\
\hline BSD vs. GDP & NA & $\mathrm{BSD}=>$ GDP & $\mathrm{BSD}=>\mathrm{GDP}$ & NA \\
\hline BSD vs. FDI & NA & BSD $\Leftrightarrow \Rightarrow$ FDI & NA & NA \\
\hline BSD vs. OPE & $\mathrm{BSD} \Leftrightarrow$ OPE & NA & NA & BSD $\Leftrightarrow \Rightarrow$ OPE \\
\hline BSD vs. INF & NA & $\mathrm{BSD}=>\mathrm{INF}$ & $\mathrm{BSD} \Leftrightarrow \Rightarrow \mathrm{INF}$ & $\mathrm{BSD}<=>\mathrm{INF}$ \\
\hline BSD vs. GCE & $\mathrm{BSD} \Rightarrow \mathrm{GCE}$ & BSD $\Leftrightarrow$ GCE & $\mathrm{BSD} \Rightarrow \mathrm{GCE}$ & $\mathrm{BSD}=>\mathrm{GCE}$ \\
\hline SMD vs. GDP & $\mathrm{SMD} \Rightarrow \mathrm{GDP}$ & SMD $\Leftrightarrow$ GDP & $\mathrm{SMD}=>\mathrm{GDP}$ & $\mathrm{SMD}=>\mathrm{GDP}$ \\
\hline SMD vs. FDI & NA & NA & FDI $\Leftrightarrow$ SMD & NA \\
\hline SMD vs. OPE & NA & SMD $\Leftrightarrow$ OPE & $\mathrm{SMD}=>\mathrm{OPE}$ & $\mathrm{SMD}=>\mathrm{OPE}$ \\
\hline SMD vs. INF & NA & SMD $\Leftrightarrow>$ INF & $\mathrm{NA}$ & $\mathrm{SMD}=>\mathrm{INF}$ \\
\hline SMD vs. GCE & $\mathrm{SMD} \Rightarrow \mathrm{GCE}$ & SMD $\Leftrightarrow$ GCE & $\mathrm{SMD}=>\mathrm{GCE}$ & $\mathrm{SMD} \Rightarrow \mathrm{GCE}$ \\
\hline GDP vs. FDI & GDP $\Leftrightarrow \Rightarrow$ FDI & $\mathrm{FDI}=>\mathrm{GDP}$ & NA & $\mathrm{FDI}=>\mathrm{GDP}$ \\
\hline GDP vs. OPE & GDP $\Rightarrow>$ OPE & GDP $\Rightarrow>$ OPE & GDP $<=>$ OPE & GDP $<\Rightarrow$ OPE \\
\hline GDP vs. INF & NA & GDP $\Rightarrow$ INF & NA & NA \\
\hline GDP vs. GCE & GDP $\Leftrightarrow \Rightarrow$ GCE & GCE $\Rightarrow$ GDP & GCE $\Rightarrow>$ GDP & NA \\
\hline FDI vs. OPE & $\mathrm{FDI}=>\mathrm{OPE}$ & $\mathrm{OPE}=>$ FDI & $\mathrm{OPE}=>$ FDI & $\mathrm{OPE}=>$ FDI \\
\hline FDI vs. INF & INF $=>$ FDI & NA & NA & NA \\
\hline FDI vs. GCE & FDI $\Leftrightarrow$ GCE & NA & $\mathrm{FDI} \Rightarrow \mathrm{GCE}$ & GCE $\Rightarrow>$ FDI \\
\hline OPE vs. INF & $\mathrm{INF}=>\mathrm{OPE}$ & $\mathrm{INF}=>\mathrm{OPE}$ & $\mathrm{INF}=>\mathrm{OPE}$ & $\mathrm{INF}=>$ OPE \\
\hline OPE vs. GCE & GCE $\Leftrightarrow=$ OPE & GCE $<=$ OPE & $\mathrm{GCE}=>\mathrm{OPE}$ & GCE $<=>$ OPE \\
\hline INF vs. GCE & INF $\Leftrightarrow$ GCE & GCE $\Rightarrow>$ INF & GCE $\Rightarrow>$ INF & GCE $\Rightarrow>$ INF \\
\hline
\end{tabular}

Note 1: GDP is per capita economic growth rate; BSD is banking sector development index; SMD is stock market development index, FDI is foreign direct investment inflows; OPE is trade openness; INF is inflation rate; GCE is government consumption expenditure. Variables are defined under Tables 3-5.

Note 2: $\mathrm{X} \Rightarrow \mathrm{Y}$ means variable $\mathrm{X}$ Granger causes Variable $\mathrm{Y}$; and $\mathrm{X} \Leftrightarrow \mathrm{Y}$ means both variables Granger cause each other; NA: No causality between the two variables. 


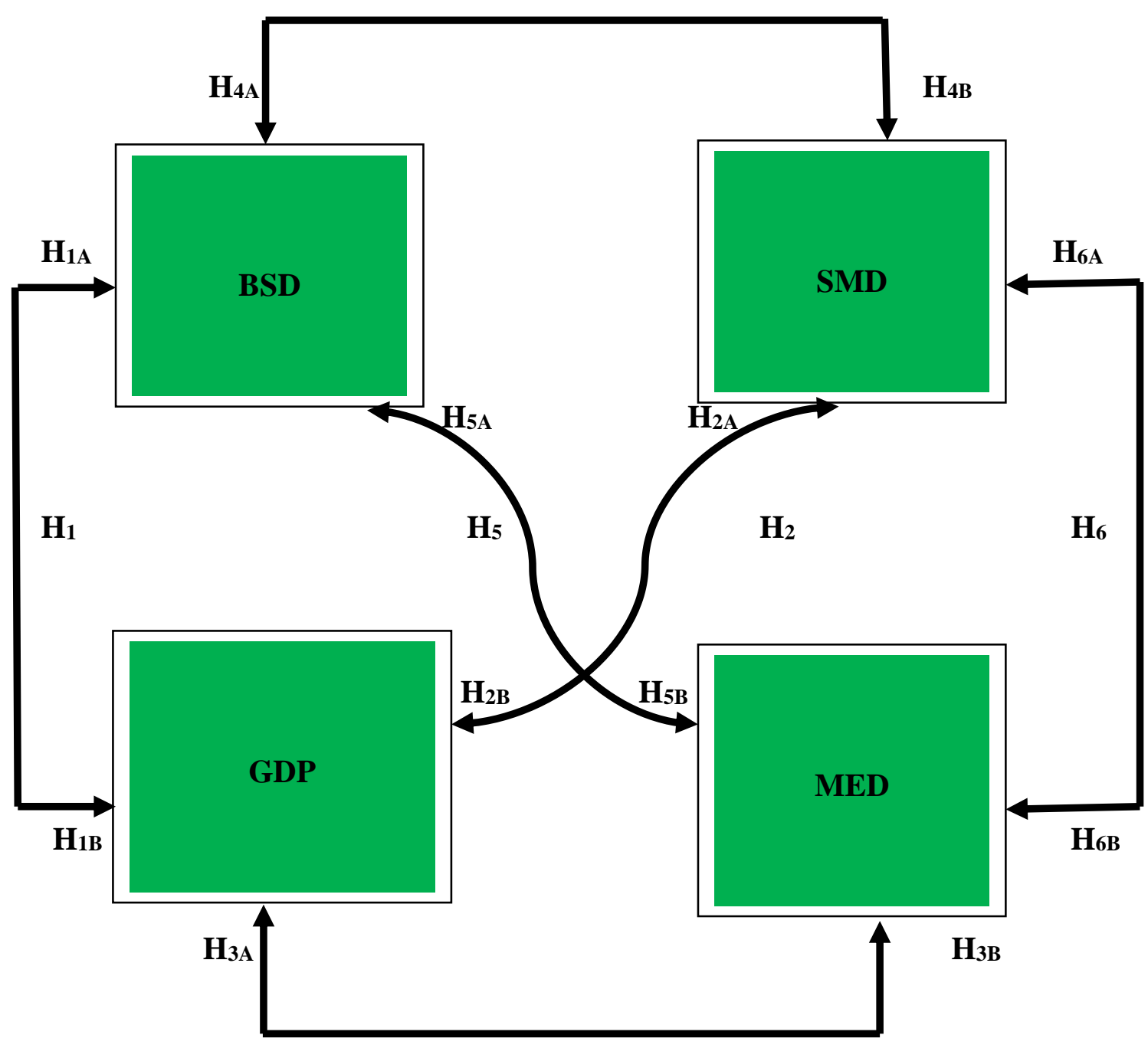

$\mathrm{H}_{3}$

Note 1: GDP is per capita economic growth rate; BSD is banking sector development; SMD is stock market development, and MED is macroeconomic development comprised of four macroeconomic variables: FDI, OPE, INF, and GCE.

Note 2: FDI: Foreign direct investment; OPE: Trade openness; INF: inflation rate; and GCE: Government consumption expenditure.

Note 3:

$\mathrm{H}_{1 \mathrm{~A}, \mathrm{~B}}$ : Banking sector development Granger-causes economic growth and vice versa.

$\mathrm{H}_{2 \mathrm{~A}, \mathrm{~B}}$ : Stock market development Granger-causes economic growth and vice versa.

$\mathrm{H}_{3 \mathrm{~A}, \mathrm{~B}}$ : A macroeconomic determinant Granger-causes economic growth and vice versa.

$\mathrm{H}_{4 \mathrm{~A}, \mathrm{~B}}$ : Banking sector development Granger-causes stock market development and vice versa.

$\mathrm{H}_{5 \mathrm{~A}, \mathrm{~B}}$ : Banking sector development Granger-causes a macroeconomic determinant and vice versa.

$\mathrm{H}_{6 \mathrm{~A}}$, $\mathrm{B}$ : Stock market development Granger-causes a macroeconomic determinant and vice versa.

Note 4: All variables are defined in Tables 3-5.

Figure 1: The Conceptual Framework of the Possible Patterns of Causality between the Variables 


\section{Research Framework}

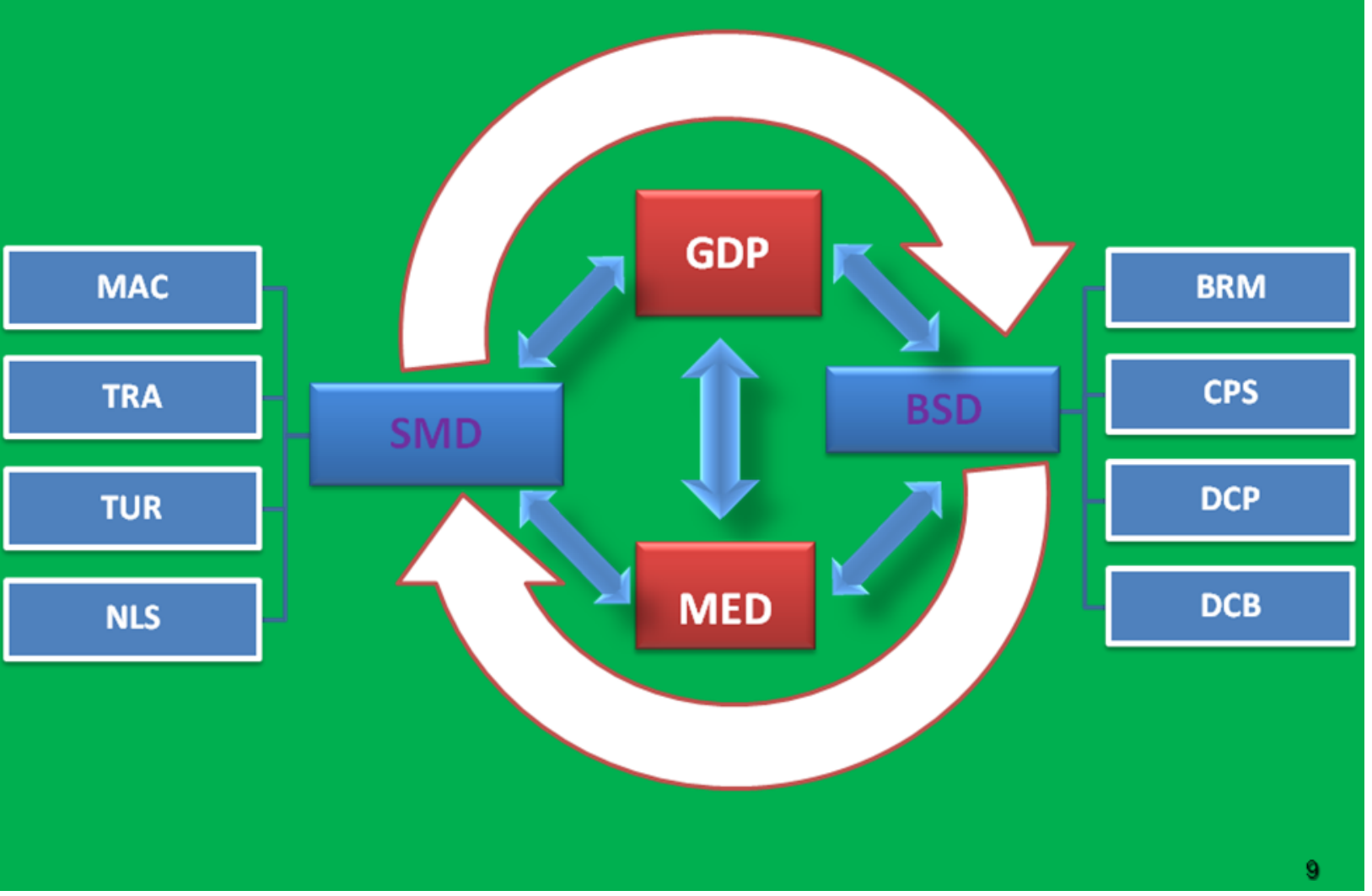

Note 1: BSD is the banking sector development index constructed from BRM, CPS, DCP, DCB; SMD is the stock market development index constructed from MAC, TRA, TUR, NLC; GDP is per capita economic growth; and MED is a set of four other macroeconomic variables: FDI (foreign direct investment), OPE (trade openness), INF (inflation rate), and GCE (government consumption expenditure).

Note 2: All variables are defined in Tables 3-5.

Figure 2: The Structural Framework on the Possible Linkages between Banking Sector Development, Stock Market Development, Economic Growth, and Four Other Macroeconomic Variables 

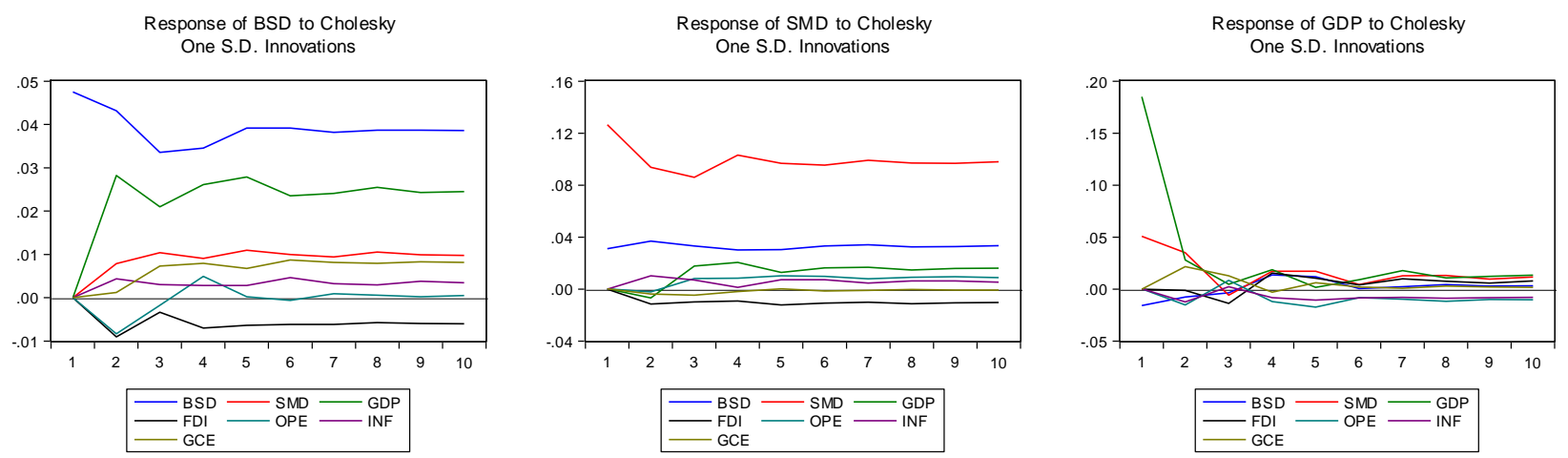

Response of FDI to Cholesky One S.D. Innovations
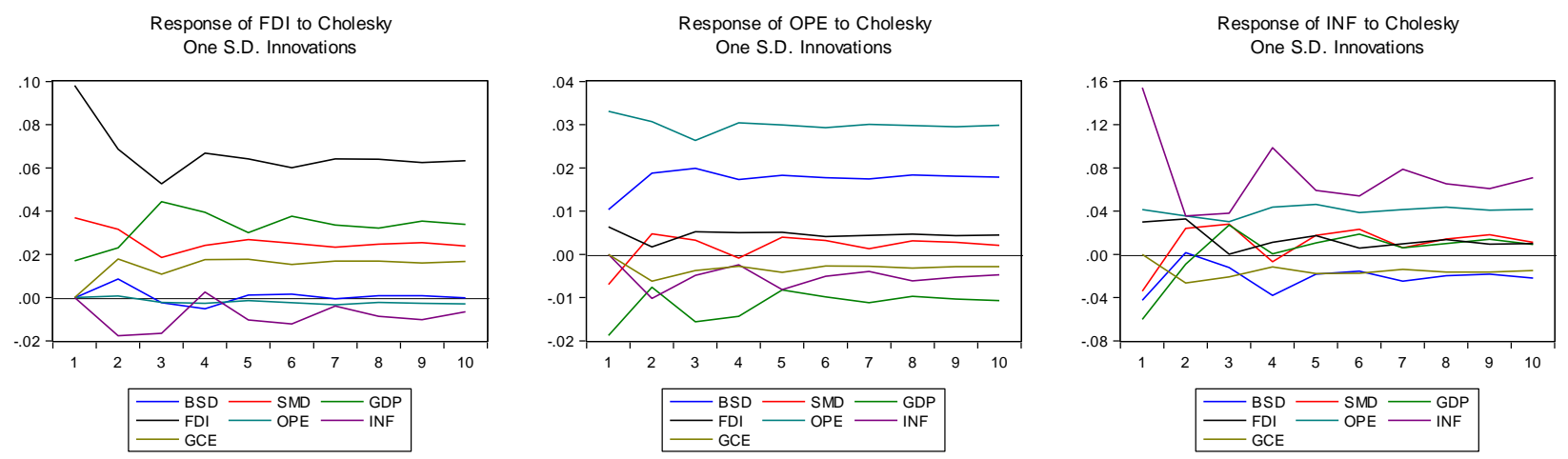

Response of GCE to Cholesky

One S.D. Innovations

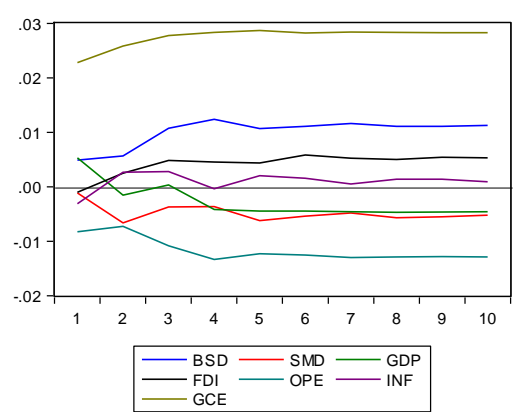

Note 1: GDP is per capita economic growth rate; BSD is banking sector development index; SMD is stock market development index, FDI is foreign direct investment inflows; OPE is trade openness; INF is inflation rate; and GCE is government consumption expenditure.

Note 2: ARF Member countries comprise the pool of ten countries, namely Brunei, Burma, Cambodia, Indonesia, Laos, Malaysia, Philippines, Singapore, Thailand, and Vietnam.

Figure 3. Granger Causal Relations between the Variables in ARF Member Countries 

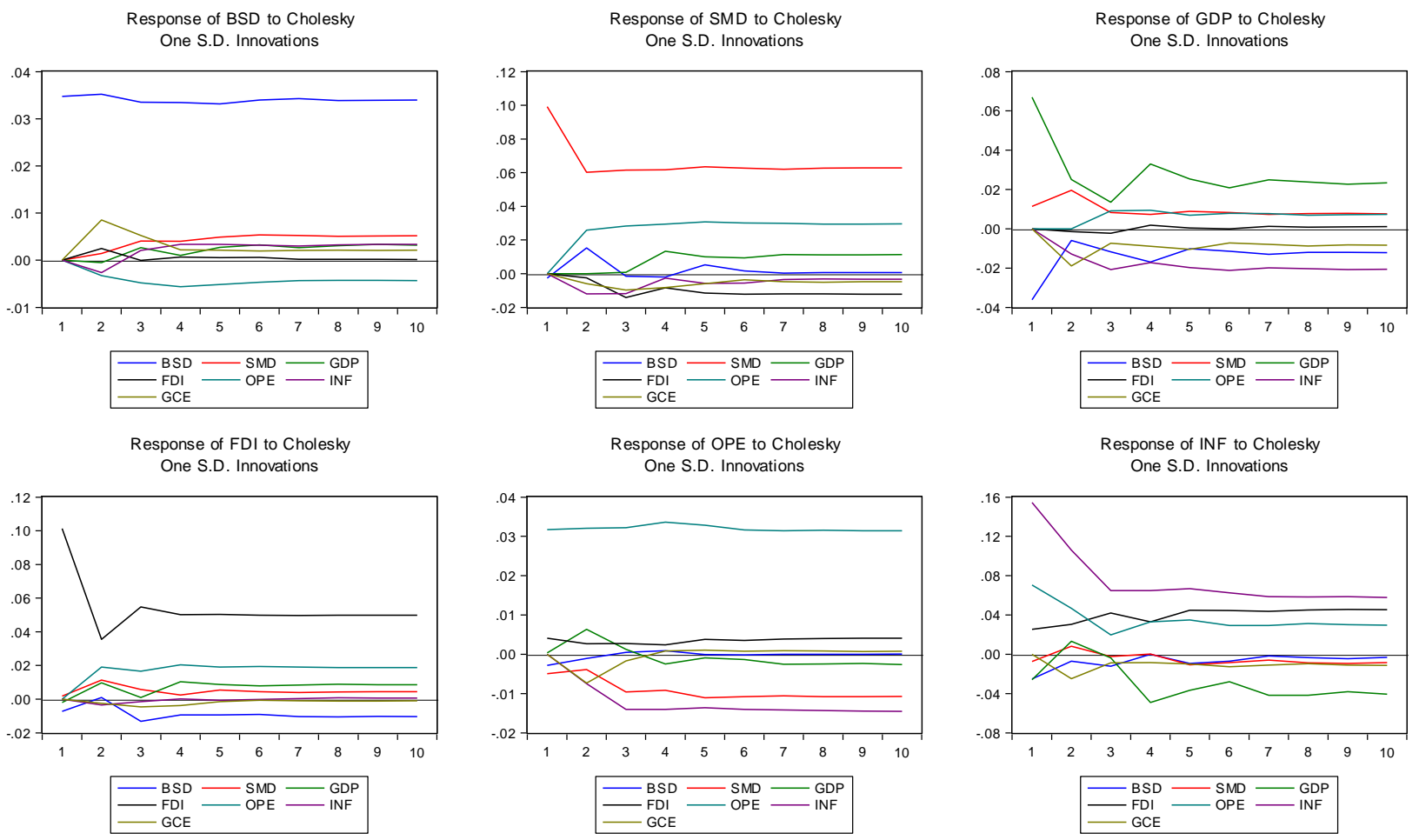

Response of OPE to Cholesky

One S.D. Innovations

Response of INF to Cholesky

One S.D. Innovations
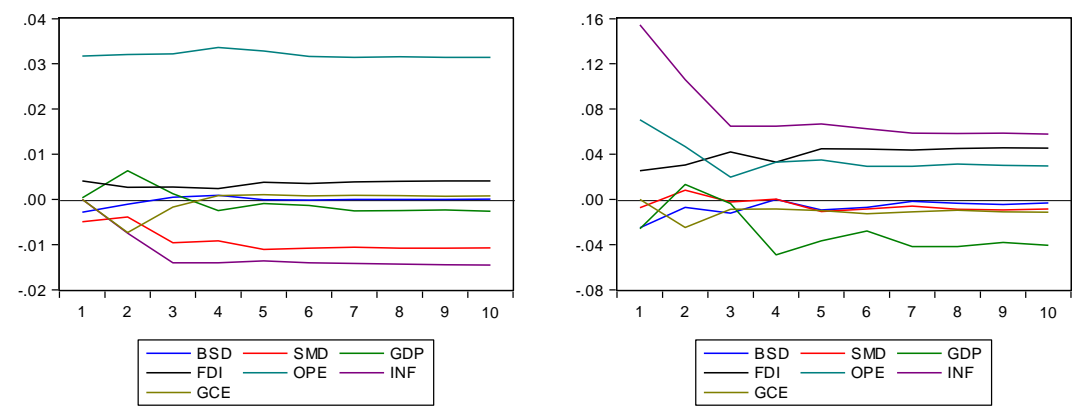

Response of GCE to Cholesky One S.D. Innovations

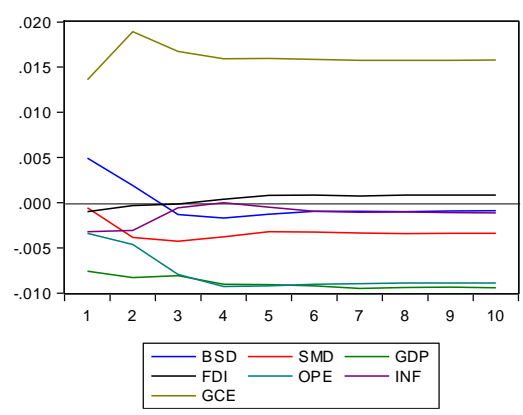

Note 1: GDP is per capita economic growth rate; BSD is banking sector development index; SMD is stock market development index, FDI is foreign direct investment inflows; OPE is trade openness; INF is inflation rate; and GCE is government consumption expenditure.

Note 2: ARF Dialogue Partners countries comprise of the pool of nine countries, namely Australia, Canada, China, India, Japan, New Zealand, the Korean Republic, the Russian Federation, and the United States.

Figure 4. Granger Causal Relations between the Variables in ARF Dialogue Partners Countries 

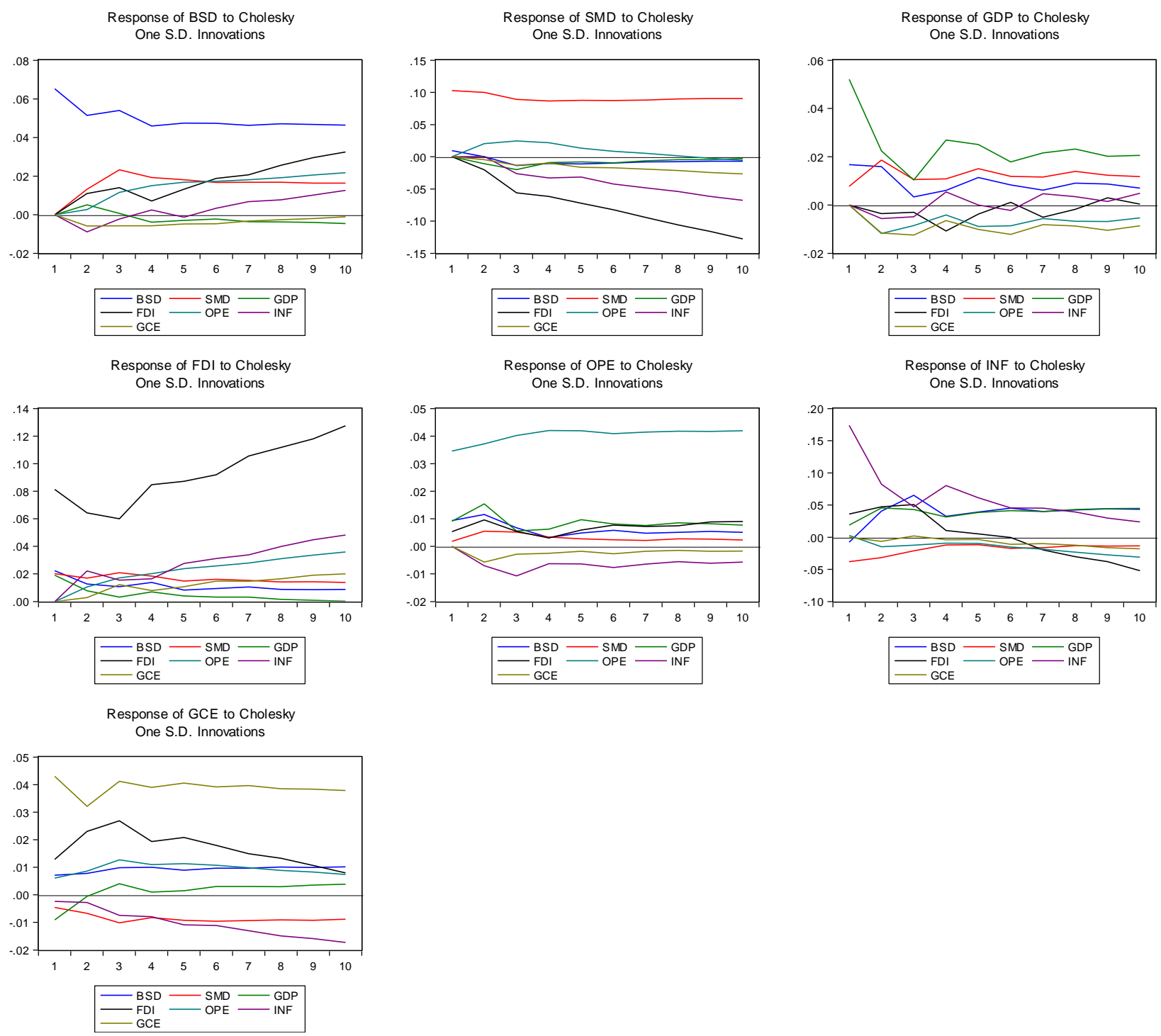

Note 1: GDP is per capita economic growth rate; BSD is banking sector development index; SMD is stock market development index, FDI is foreign direct investment inflows; OPE is trade openness; INF is inflation rate; and GCE is government consumption expenditure.

Note 2: ARF Observer countries comprise of the pool of six countries, namely Papua New Guinea, Mongolia, Pakistan, East Timor, Bangladesh, and Sri Lanka.

\section{Figure 5. Granger Causal Relations between the Variables in ARF Observer Countries}



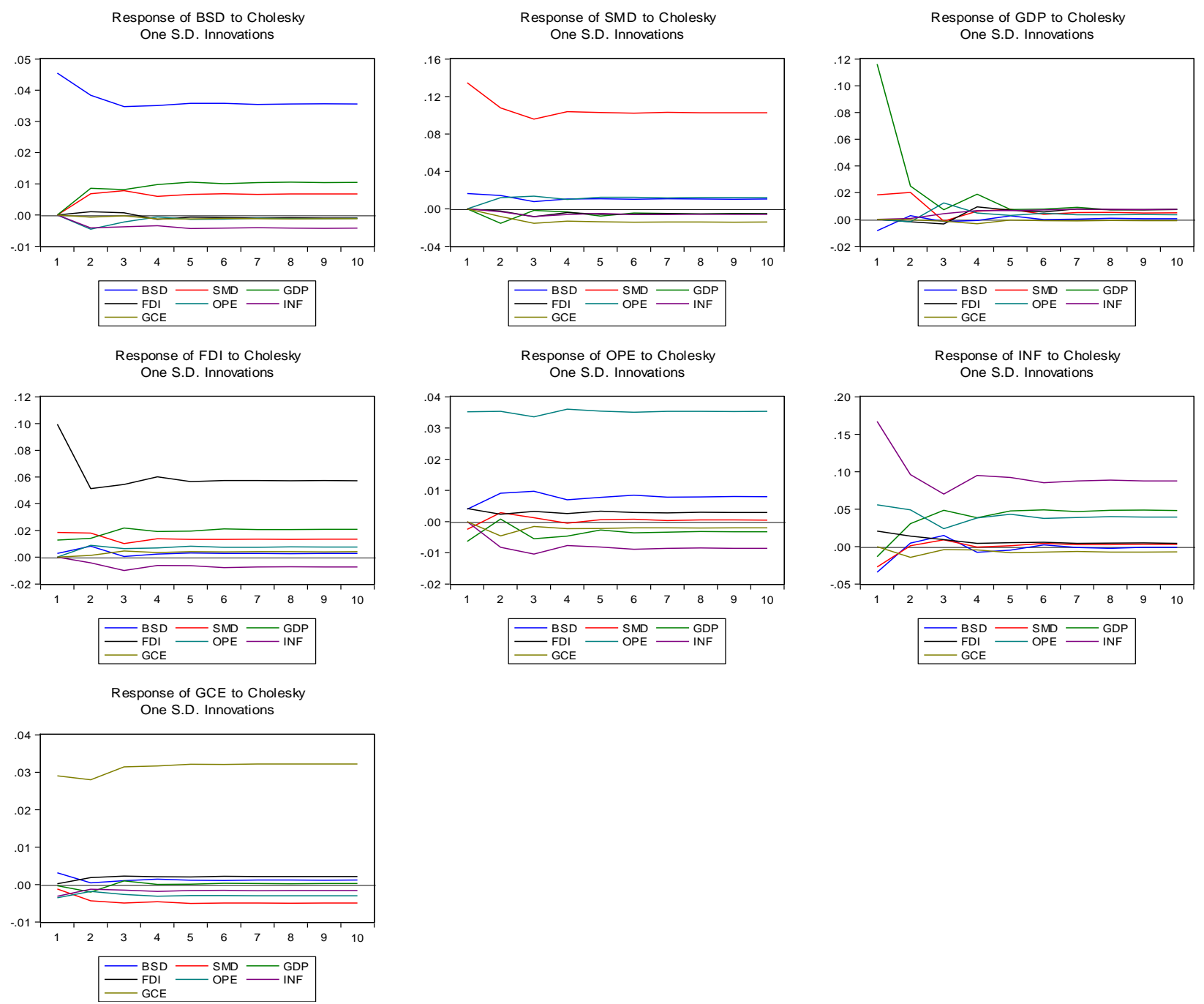

Note 1: GDP is per capita economic growth rate; BSD is banking sector development index; SMD is stock market development index, FDI is foreign direct investment inflows; OPE is trade openness; INF is inflation rate; and GCE is government consumption expenditure.

Note 2: ARF Total countries comprise of the pool of 25 countries, namely Brunei, Burma, Cambodia, Indonesia, Laos, Malaysia, Philippines, Singapore, Thailand, Vietnam, Australia, Canada, China, India, Japan, New Zealand, the Korean Republic, the Russian Federation, the United States, Papua New Guinea, Mongolia, Pakistan, East Timor, Bangladesh, and Sri Lanka.

Figure 6. Granger Causal Relations between the Variables in ARF Total countries 